ENCUESTA 



\section{ENCUESTA SOBRE EL GOBIERNO EN FUNCIONES}

\section{PRESENTACIÓN}

Teoría y Realidad Constitucional ha prestado particular atención en encuestas anteriores a la institución del Gobierno, obviamente capital en todo sistema constitucional. En nuestro número 14 dedicamos la encuesta a analizar la naturaleza y competencias del órgano del poder ejecutivo y, en el 19, una segunda versaría sobre su necesario y complejo control jurídico político.

Pero, como bien saben los lectores habituales, tras la profunda crisis económica y social que ha aquejado a nuestra vieja tierra, los principales partidos políticos del tradicional bipartidismo imperfecto español vieron reducir su caudal electoral en los comicios electorales de 2015, en que el respaldo que el cuerpo electoral otorgó a las nuevas formaciones políticas aportó un Congreso de los Diputados pluripartidista. Ello conllevaba la superación de la dinámica postelectoral de investidura de un nuevo Presidente del Gobierno. Como era bien sabido, en las legislaturas en que ninguno de los dos partidos tradicionales había obtenido la mayoría absoluta de la Cámara baja se centraba en que el partido con mayor representación procuraba el apoyo de una o varias fuerzas nacionalistas. En el nuevo escenario parlamentario, como todos recordamos, se podía percibir la ausencia de los hábitos y de la experiencia que ostentan los dirigentes de las fuerzas políticas de los sistemas pluripartidistas europeos. Las preguntas que agrupamos al principio de la encuesta procuran que nuestros muy cualificados encuestados nos arrojen luz sobre estas dificultades novedosas por nuestros lares.

Y los medios de comunicación social llamaron la atención sobre nuestra opinión pública acerca de lo que unos consideraban un pertinente acrecentamiento del rol del Rey en este trance postelectoral y otros entendían como la prueba de la conveniencia de prestar atención a las mejores experiencias de algunas monarquías parlamentarias europeas en países de larga tradición pluripartidista y terceros comentaristas veían que nuestro monarca parlamentario debía abstenerse de desempeñar cualquier papel significativo en tan compleja coyuntura. Es esta la materia suscitada por las cuestiones agrupadas en segundo lugar para poder obtener buenos criterios de nuestros invitados.

Obviamente, la nueva composición de los grupos parlamentarios, que prolongó la vida del Gobierno en funciones durante más de trescientos días, fue la 
coyuntura en que de los propios ministros emanaron resistencias a someterse al control parlamentario, aduciendo que el nuevo Congreso de los Diputados no era con el que en la legislatura anterior se había formado el Gobierno ahora en funciones. Esa nueva realidad suscitaba a los constitucionalistas españoles numerosos interrogantes sobre si siendo una de las ideas fuerza del Estado democrático de Derecho el que su poder político esté controlado jurídica y políticamente, hasta qué punto ello podía no aplicarse o matizarse cuando el Gobierno se encontraba en funciones. Y a esta delicada temática dedicamos en nuestra encuesta las últimas preguntas.

Por ser conscientes de la importancia de las cuestiones planteadas y de que la bibliografía producida al respecto hasta hoy por los constitucionalistas españoles no es muy numerosa y en parte se ha elaborado a la vista de un sistema representativo que había venido siendo de bicameralismo imperfecto, a quienes fraguamos Teoría y Realidad Constitucional nos han surgido más interrogantes que los habituales en nuestras encuestas. Y, a la par, hemos procurado invitar a que nos faciliten sus doctas respuestas a prestigiosos profesores, que representan posiciones académicas diferentes o complementarias y que anteriormente han escrito acerca de los delicados puntos respecto de los que les demandamos luz.

A la vista de la riqueza de las aportaciones que nuestros encuestados han aportado y que agradecemos particularmente, confiamos en que los agudos lectores puedan disfrutar con los diálogos tácitos que se establecen sobre las materias controvertidas.

\section{CUESTIONES}

1. ¿Considera que debe mejorar la cultura politica y el comportamiento de los dirigentes de los partidos políticos en el trance postelectoral de formar una mayoría de Gobierno en un Congreso de los Diputados de composición pluripartidista? ¿Convendría pensar flexibilizar lo dispuesto en el art. 99.5 de la CE sobre el plazo preclusivo de dos meses, a partir de la primera votación de investidura sin que ningún candidato bubiere obtenido la confianza del Congreso, que desencadena la convocatoria de nuevas elecciones?

2. A la vista de las experiencias recientes, ¿Qué opinión nos puede dar sobre el papel del Rey en su propuesta al Congreso de los Diputados de candidato a Presidente del Gobierno? ¿Cree que el refrendo por el Presidente del Congreso debe ser entendido de forma que no deje ningún margen de impulso al Rey? ¿Amén de la consulta con los representantes designados por los Grupos políticos con representación parlamentaria, tendría sentido que el Rey tuviera la prerrogativa de escuchar a algún informador, en forma similar a como se opera en la monarquía bolandesa?

3. ¿Qué importancia concede usted al control político por las Cámaras del Gobierno, cuando está en funciones? ¿El que un Gobierno tras la celebración de elecciones generales esté en funciones, supone a su juicio una supresión o aminoración de las competencias 
específicas de control que las Cámaras y sus comisiones tienen respecto del Gobierno y cada uno de sus miembros?

4. ¿En qué casos o en base a qué circunstancias a su juicio un Gobierno en funciones se puede negar a someterse al control parlamentario? ¿En la Ley del Gobierno vigente o en los Reglamentos del Congreso y del Senado hay apoyatura para que un Gobierno no se someta al control parlamentario de alguna de sus actividades? ¿Qué otra valoración querría realizar sobre el ámbito de actuación de un Gobierno en este estado?

5. A la vista de la participación de los Gobiernos y de los Estados en el proceso de decisión de la Unión Europea, ¿podría hacernos alguna reflexión sobre cómo debería articularse en este terreno la actuación de un Gobierno en funciones y sobre si habria de estar sometida a control por parte de las Cámaras?

\section{ENCUESTADOS}

JAVIER GARCIA FERNANDEZ. Universidad Complutense de Madrid ANGEL JOSÉ GOMEZ MONTORO. Universidad de Navarra JOSÉ ANTONIO MONTILLA MARTOS. Universidad de Granada MIGUEL REVENGA SANCHEZ. Universidad de Cádiz FERNANDO REVIRIEGO PICÓN. Universidad Nacional de Educación a Distancia

M. ${ }^{a}$ JOSEFA RIDAURA MARTINEZ. Universidad de Valencia

MARÍA ESTHER SEIJAS VILLADANGOS. Universidad de León

\section{RESPUESTAS}

1. ¿Considera que debe mejorar la cultura política y el comportamiento de los dirigentes de los partidos políticos en el trance postelectoral de formar una mayoría de Gobierno en un Congreso de los Diputados de composición pluripartidista? ¿Convendría pensar flexibilizar lo dispuesto en el art. 99.5 de la CE sobre el plazo preclusivo de dos meses, a partir de la primera votación de investidura sin que ningún candidato bubiere obtenido la confianza del Congreso, que desencadena la convocatoria de nuevas elecciones?

\section{JAVIER GARCIA FERNANDEZ}

En lo que se refiere a la primera pregunta creo que, efectivamente, debe mejorar la cultura política y el comportamiento de los dirigentes de los partidos políticos. Como hasta 2015 (salvo en 1996), el resultado de las elecciones prefiguraba la formación del Gobierno, no habíamos percibido la frivolidad, desconocimiento constitucional y hasta pereza de muchos dirigentes políticos españoles. 
Con los resultados del 20 de diciembre de 2015 el día 21, tendrían que haber empezado a negociar, como poco, Rajoy, Sánchez, Iglesias Turrión y Rivera. Pero prefirieron pasar en familia o en la nieve las vacaciones de Navidad. Y llegaron a entrevistarse con el Rey sin los «deberes» realizados. De ahí actos tan lamentables como (por orden cronológico) el hecho de que Rajoy «declinara» la propuesta del Monarca (después de que en los días siguientes a las elecciones el Partido Popular afirmara varias veces que debería formar Gobierno el partido que más escaños hubiera obtenido), que Iglesias Turrión diera una rueda de prensa coral cuando Sánchez estaba entrevistándose con Felipe VI, que Sánchez empezara a negociar con Ciudadanos y con Podemos después de que el Rey formulara la propuesta (y no antes) y de que Podemos hiciera un ficción de negociación con el P.S.O.E. cuando este partido ya había decidido impedir que Sánchez formara Gobierno.

Estos hechos (a mi juicio, bastante vergonzosos) traen causa de que los partidos (o sus dirigentes) no han entendido el sentido del apartado 1 del artículo 99 de la Constitución. A diferencia de otros sistemas parlamentarios, la Constitución española no ha previsto que el Rey «encargue» formar Gobierno a un determinado político. Más bien es al revés, esto es, cuando acuden a la entrevista con el Rey, los dirigentes políticos tienen que llegar con el trabajo hecho, es decir, habiendo negociado entre sí (a este respecto, Javier García Fernández: «Mitos sobre la investidura», El País, 2 de enero de 2016). Pero esa actuación, que tiene sólidos fundamentos constitucionales porque lo contrario daría al Monarca un protagonismo que la Constitución deliberadamente no le otorga, no ha sido entendida por los dirigentes de los principales partidos, que acudieron a la entrevista con el Rey a ver qué pasaba.

En cuanto a la segunda cuestión de esta pregunta, creo, efectivamente, que convendría flexibilizar lo dispuesto en el artículo 99.5 de la Constitución sobre el plazo preclusivo de dos meses, a partir de la primera votación de investidura sin que ningún candidato hubiere obtenido la confianza del Congreso, que desencadena la convocatoria de nuevas elecciones. El artículo 99.5 de la Constitución estaba muy bien pensado para evitar que el Rey propusiera candidatos imposibles que podrían provocar la paralización de la vida política pero es verdad que en 2016 hemos descubierto que provoca un efecto no deseado y por ello tiene también inconvenientes. Yo creo que se debe modificar la Constitución para aplicar cierto automatismo en la elección del Presidente. Por ejemplo, se podría establecer que si después de dos (o tres) meses desde la primera votación de investidura no se ha elegido al Presidente del Gobierno, el Presidente del Congreso propondrá al Rey el nombramiento del Diputado que designe el primer Grupo Parlamentario de la Cámara. Esta procedimiento tiene el inconveniente de que se tratará, en principio, de un Presidente parlamentariamente muy débil pero, a cambio, obligaría a un alto grado de consenso y de negociación porque si una persona es elegida Presidente del Gobierno (aun por este procedimiento) tendrá suficiente interés en permanecer en el cargo. 


\section{ÁNGEL J. GÓMEZ MONTORO}

Considero que, efectivamente, la complicada situación vivida en España desde las elecciones de 20 de diciembre de 2015 hasta la disolución de las Cortes y subsiguiente convocatoria de elecciones ha puesto de relieve algunas importantes carencias de nuestra cultura política. Es cierto que la crisis vivida ha evidenciado también algunos problemas de la regulación contenida en el art. 99 CE, pero — con la salvedad que enseguida diré- creo que los problemas no han sido principalmente jurídicos y que la regulación prevista en el mencionado precepto es básicamente satisfactoria.

La situación vivida se debe, fundamentalmente, a una falta de entendimiento (cuando no de simple respeto) de lo que implica un régimen de monarquía parlamentaria, como es el que establece nuestra Constitución. Tras unas elecciones, los partidos políticos con representación parlamentaria tienen la obligación de coadyuvar a la formación de un nuevo Gobierno y de colaborar lealmente con el Rey para que este pueda cumplir su obligación de proponer un candidato a la Presidencia del Gobierno. El partido más votado tiene inicialmente la obligación de intentar su formación, solo o en coalición, y los partidos de la oposición no deben impedir la formación del Gobierno salvo que tengan una alternativa real. El proceso de investidura tiene como finalidad elegir al Presidente y, a su través, la formación de un nuevo Gobierno y no debería ser utilizado como arma de desgaste político; o al menos no hasta el punto de llegar a situaciones de bloqueo que avoquen a nuevas elecciones que, muy previsiblemente, no ofrecerán resultados significativamente diferentes. La razonable confrontación política tiene su lugar natural durante la campaña electoral y la labor de control - y hasta de desgaste, si se quiere- del Gobierno procede una vez que este se ha formado, pero la disputa partidista no debería llevar en el futuro a una situación como la vivida, de simple bloqueo institucional.

Es verdad que los problemas que se han planteado podrían explicarse por una fragmentación política inédita desde que se aprobó la Constitución. Creo, sin embargo, que ello no explica por sí solo lo ocurrido, y no faltan ejemplos de países (e incluso en nuestras Comunidades Autónomas) donde un Parlamento fraccionado no ha impedido la formación de Gobiernos. Creo más bien que lo que la crisis ha evidenciado es una manera no adecuada de entender la labor de los partidos políticos en un régimen parlamentario: su principal misión no es alcanzar el gobierno a cualquier precio sino colaborar a la gobernabilidad del país, bien asumiendo tareas de gobierno, bien desde la oposición y preparándose para asumirlas en el futuro cuando se produzca la natural alternancia. En los últimos años, sin embargo, se percibe un mayor protagonismo del deseo de alcanzar - $\mathrm{O}$ de permanecer en- el poder a cualquier precio, que se traduce con más frecuencia de la que puede aguantar un régimen democrático, en una ausencia de diálogo y de pactos. Manifestaciones de esta preocupante tendencia se aparecían, desde hace años, en la reiterada incapacidad de renovar en plazo los órganos 
constitucionales o de llegar a pactos de Estado en materias donde todos coinciden sobre su urgencia (educación, pensiones, justicia...).

Por lo que se refiere a la segunda pregunta, no soy partidario de ampliar el plazo de dos meses previsto en el apartado 5 del art. 99 CE. Creo que es tiempo suficiente para comprobar si existe o no una alternativa viable de gobierno. Sí considero necesario, a la vista de la experiencia vivida, introducir un plazo (quizás de un mes) para que se produzca la primera propuesta de candidato y, en todo caso, fijar un plazo para la disolución automática no desde la primera votación del candidato sino desde la constitución del Congreso (que podría ser de tres meses), evitando así que la situación de interinidad pueda prolongarse indefinidamente por la simple incapacidad de llegar a acuerdos.

\section{JOSÉ ANTONIO MONTILLA MARTOS}

No es un problema únicamente de cultura política o de ausencia de cultura de pacto. A mi juicio, el bloqueo político que hemos sufrido durante casi un año, entre diciembre de 2015 y octubre de 2016, ha sido el resultado de unas concretas circunstancias políticas, con componentes coyunturales y otros que parecen estructurales. Ello nos ha permitido advertir algunas deficiencias en la regulación jurídico-constitucional que hasta ahora habían pasado inadvertidas. Las mencionadas circunstancias políticas han hecho imposible el acuerdo para la investidura del Presidente del Gobierno en un sistema político muy fragmentado y sin ese acuerdo la única salida que ofrece el artículo $99 \mathrm{CE}$ es la repetición continua del proceso electoral. Intentaré explicarme en unas líneas, so riesgo de ser impreciso.

Es evidente que las elecciones generales del 20 de diciembre de 2015 han supuesto el tránsito de un sistema bipartidista imperfecto a un sistema multipartidista, en ambos casos con la presencia adicional de grupos nacionalistas. Y no olvidemos que nuestro sistema político estaba diseñado desde su origen en la transición política para un escenario de bipartidismo. Desde las elecciones de 1977 se asentó la idea de que las pequeñas circunscripciones garantizaban una mayoría parlamentaria para dos grandes partidos, sin perjuicio de que otros grupos políticos de ámbito estatal tuvieran una pequeña representación gracias a las circunscripciones mayores o los grupos nacionalistas obtuvieran representación en sus respectivos territorios. El resto del modelo se configuraba a partir de ese presupuesto. En este sentido, la formación de gobierno no parecía plantear problemas. Se presumía que uno de los dos grandes partidos iba a poder formar gobierno, siquiera con el apoyo de grupos minoritarios. Así había ocurrido en las diez legislaturas anteriores (once, si contamos la 1977-1979). Sin embargo, tras las elecciones de 2015 se advierten algunas novedades en el escenario político que van a imposibilitar un acuerdo de investidura. En primer lugar, como se ha dicho, ya no hay dos partidos claramente hegemónicos. Los dos partidos que se habían 
alternado en el gobierno, con unos porcentajes de voto de hasta el $84 \%$ obtienen en 2015 apenas el 50\% de los votos. Ahora cuatro partidos de ámbito estatal compiten por obtener escaño en prácticamente todas las circunscripciones. Así, en algunas circunscripciones en las que se eligen tres o cuatro diputados éstos se reparten entre tres o cuatro grupos políticos distintos. Además, en segundo lugar, uno de los nuevos partidos, Podemos, se presenta como partido de ruptura, reacio, por tanto, a una cultura de pacto identificado con un régimen político que aspira a superar a través de un proceso constituyente. En tercer lugar, el partido ganador de las elecciones y, por tanto, en torno al que debería articularse la formación del gobierno, tiene un importante déficit de legitimidad por los numerosos casos de corrupción en el que están implicados no sólo sus miembros sino el propio partido, lo que hace más difícil no sólo el acuerdo sino incluso dejarlo gobernar. Y, finalmente, en cuarto lugar, los partidos nacionalistas catalanes que en muchas legislaturas habían facilitado la gobernabilidad, tanto CiU como ERC, se presentan ahora como abiertamente independentistas, embarcados en un proceso unilateral de secesión, lo que, lógicamente, impide contar con ellos para la formación de gobierno. Sin negar que en España falta cultura política de pacto, ha sido la concurrencia temporal de todos estos elementos lo que ha dificultado la formación de gobierno tanto tras las elecciones generales de 20 de diciembre de 2015 como tras las de 26 de junio de 2016.

$\mathrm{Y}$ en este contexto se ha advertido que la regulación constitucional de la formación de gobierno no permitía la superación del bloqueo político sino que, por el contrario, algunos de sus contenidos lo favorecían. Así, en primer lugar, si ningún candidato a la investidura quiere ser propuesto, y el Rey no tiene capacidad de impulso como se expondrá en la siguiente respuesta, nunca se celebrará la votación de investidura y, en consecuencia ni se formará gobierno ni podrán celebrarse nuevas elecciones. En segundo lugar, una vez realizada la primera votación de investidura, si ningún candidato es investido en el plazo de dos meses, desembocamos inexorablemente en nuevas elecciones. Y esto, una y otra vez. Se pueden estar repitiendo sine die las elecciones en el caso de que ningún candidato obtenga la mayoría necesaria para ser investido, esto es, tenga más votos a favor que en contra.

La lógica del modelo diseñado por el artículo 99 es evidente, y no parece necesario incidir sobre ello. Se trata de garantizar que el candidato investido cuente con la confianza del Congreso para el desarrollo de su programa de gobierno. El problema es, como hemos visto, que esa exigencia constitucional de confianza parlamentaria expresa, al menos más votos a favor que en contra, dificulta la formación del gobierno en escenarios políticos fragmentados y convulsos como el actual.

Por ello, el dilema que se plantea es si debería matizarse esa exigencia de confianza expresa del Congreso en aras de garantizar la formación de gobierno y, con ello, evitar la inestabilidad y el deterioro del sistema político derivado del mantenimiento de una situación de interinidad, o debería mantenerse incólume 
la actual regulación jurídico-constitucional en cuanto la más adecuada para un sistema parlamentario de gobierno. Se pueden aportar argumentos en favor de ambas posiciones. Para defender el mantenimiento de la situación actual puede recordarse que en otros Estados también se suelen producir largos periodos de gobiernos en funciones. Suele traerse a colación el caso de Bélgica y su año y medio con gobierno en funciones. A partir de esa experiencia se sostiene que no funciona necesariamente peor el gobierno en esos periodos de interinidad. Sin embargo, me parece una boutade defender que es preferible un Estado sin una dirección política en pleno uso de sus competencias, salvo que se parta de una concepción tecnocrática, más que democrática, del ejercicio del poder. La celebración de elecciones debe desembocar en la formación de un gobierno que responda a la manifestación de voluntad del cuerpo electoral. También puede recordarse que la investidura automática para garantizar la formación del Gobierno estaba prevista en algunos Estatutos de Autonomía como el de Andalucía o el de Navarra y fue eliminada precisamente para garantizar que el Gobierno contara siempre con la confianza del Parlamento como procede en un sistema parlamentario de gobierno. Finalmente, se puede sostener que nuestros grupos políticos terminarán acostumbrándose al pacto, si este sistema político fragmentado que ha resultado de las elecciones generales de 2015 y 2016, y se había advertido también en las autonómicas de 2015, termina por consolidarse. En muchos países europeos con un sistema político pluripartidista son habituales los acuerdos de gobierno y en las propias CCAA, tras las elecciones de 2015, se formaron en todas ellas gobiernos de coalición o se suscribieron acuerdos de investidura.

En cualquier caso, aun teniendo en cuenta los anteriores argumentos, me decanto por una modificación del artículo 99 CE para garantizar la formación de un Gobierno tras la celebración de elecciones generales o en los otros supuestos constitucionalmente previstos. Dicho con simpleza me parece mejor un gobierno sin la confianza mayoritaria del Congreso que ningún gobierno. Ese Gobierno, una vez constituido, deberá buscar acuerdos concretos para aprobar sus iniciativas. Seguramente le resultará más fácil conseguir estos acuerdos específicos que el apoyo solemne para la investidura, como acabamos de comprobar en la negociación presupuestaria. En cualquier caso, si transcurrido un año desde la anterior disolución de las Cortes, el Presidente considera que no puede desarrollar su acción de gobierno siempre podrá utilizar la disolución presidencial (art. 115 $\mathrm{CE}$ ); de la misma forma que la oposición, si consigue ahormar una mayoría alternativa, podrá plantear en cualquier momento una moción de censura (art. 113 CE).

En este sentido, sostengo una modificación del art. 99 que garantice la formación de gobierno y el inicio efectivo de la legislatura. Esa modificación no es compleja siempre que exista, obviamente, acuerdo político, pues debe seguirse el procedimiento del artículo $167 \mathrm{CE}$. A mi juicio, se trataría de eliminar los dos puntos de bloqueo a los que aludía al inicio. En primer lugar, los dos meses a los que se refiere el 99.5 CE deberían empezar a contar desde el momento en que el 
Rey termina las consultas políticas, haga o no propuesta de candidato. Para ello, es necesaria la reforma constitucional pues no estamos ante una laguna susceptible de interpretación sino ante una clara dicción constitucional que, en su caso, debería ser modificada. No es posible utilizar atajos como había planteado algún Informe de la Abogacía del Estado. En segundo lugar, la consecuencia del transcurso de esos dos meses no debería ser la disolución de las cámaras y la convocatoria de nuevas elecciones sino la celebración de una votación en la que resultará investido el candidato que obtenga un mayor número de votos. Es, en esencia, el modelo que se recoge en los reglamentos parlamentarios de País Vasco o Asturias, distinto al previsto en el Estatuto de Castilla-la Mancha, donde se prevé la investidura automática de quien encabece la lista que ha obtenido el mayor número de escaños o en la LOREG (art. 196 c) para la elección como alcalde en segunda votación de quien encabece la lista con el mayor número de votos. No se trata de investir al más votado sino al candidato que concita el mayor número de apoyos aunque estos no supongan la mayoría simple.

\section{MIGUEL REVENGA SANCHEZ}

Quiero pensar que la tesitura que se vivió en España entre las elecciones generales de diciembre de 2015 y la investidura in extremis de Mariano Rajoy un año más tarde será difícil que se presente de nuevo. Nuestro sistema parlamentario se fue conformando, desde los momentos iniciales de su andadura, sobre el presupuesto de dos grandes fuerzas políticas que obtenían del electorado el apoyo necesario y suficiente como para que la contienda electoral fuera dirimente en cuanto a cuál de ellas tenía que gobernar. El fantasma de la inestabilidad gubernamental estuvo en el origen de un diseño constitucional que propició ese y no otro sesgo de nuestro parlamentarismo, pero lo sucedido durante la larga crisis política de 2016 demuestra, a mi juicio, una verdad que bien podría ser calificada como «la verdad del barquero»: el parlamentarismo es una forma de gobierno cuyo funcionamiento efectivo reposa sobre la disposición efectiva de las fuerzas políticas a sostener los compromisos que sean necesarios para hacerlo viable. Y como consecuencia de dicha verdad, y mal que nos pese: las reglas jurídicas sobre el funcionamiento del parlamentarismo lo enmarcan en ciertos contornos —unos contornos que versan sobre el juego inter-institucional - pero sería impropio decir que lo disciplinan; lo canalizan $\mathrm{y}$, si se quiere, lo condicionan, pero no hasta el punto de convertirse en factor determinante. Dicho lo cual, me parece que la primera parte de la pregunta está contestada. Ciertamente las mejoras en la cultura política de la dirigencia (como se dice ahora) de los partidos es siempre deseable. Entre otras cosas, porque la prueba de fuego para cualquiera que haga de la política su profesión ocasional o permanente es la capacidad para manejarse en un contexto en el que la pluralidad de puntos de vista, a menudo contrapuestos, exige una disposición 
a dialogar que es consustancial a la política democrática. Más allá del respeto a los consensos constitucionales básicos, por sí mismos moldeables y abiertos también a reformas, la sobreabundancia de «líneas rojas» que no se pueden traspasar y la dialéctica de «vetos recíprocos» (que es una versión por fortuna pacífica de aquella de los puños y las pistolas) son síntomas de una cultura política deficitaria desde el punto de vista democrático. Máxime cuando lo que se pone en juego es la «lectura» de una voluntad del pueblo soberano recién expresada en las urnas, cuya complejidad nunca debería ser argumento para imposibilitar su gestión, sino acicate para «digerirla». En lo que se refiere a la cuestión del plazo de los dos meses desde la primera votación de investidura como espoleta que activa el camino hacia la convocatoria de nuevas elecciones, a mi juicio está bien como está. Creo que el artículo 99 de la Constitución, en cuanto al fondo, pero también en cuanto a las formas y plazos temporales, combina sabiamente ingredientes de incertidumbre e ingredientes de certeza, de manera tal que hay margen de flexibilidad para establecer el «dies a quo», pero también hay firmeza al contemplar un horizonte de dos meses como un plazo más que razonable de tiempo para evitar la nueva llamada a las urnas.

\section{FERNANDO REVIRIEGO PICÓN}

La irrupción de nuevos partidos políticos con un amplio respaldo popular en los últimos procesos electorales ha alterado, qué duda cabe, el panorama político de bipartidismo imperfecto, abisagrado con partidos nacionalistas, al que estábamos acostumbrados. Se dio paso así tras las elecciones generales de diciembre de 2015 y junio de 2016 a un escenario — ya anticipado en las europeas de 2014_, de «multipartidismo exasperado» (Elia, La continuitá nel funzionamento degli organi costituzionali, 1958)_, que complicó la formación del Gobierno, así como a una sucesión de hechos y situaciones inéditas hasta el momento. Hasta ese momento habíamos contado con un Congreso de los Diputados en las que los dos principales partidos se repartían aproximadamente más del ochenta o noventa por ciento de los escaños; partidos sobre representados siempre en el reparto de escaños respecto de los sufragios recibidos, por una multiplicidad de factores como la circunscripción provincial, la existencia de magnitudes no muy amplias o la propia fórmula electoral elegida para el Congreso - junto con las listas cerradas y bloqueadas, esos elementos «provisionales» y nada inocentes del Real Decreto Ley 20/1977, que finalmente vinieron para quedarse. En cuatro ocasiones, incluso, un solo partido llegó a obtener la mayoría absoluta de diputados (1982, 1986, 2000, 2011), y, en una quinta (1989), quedándose apenas a un escaño de la misma. Este paisaje quedó trastocado severamente tras esas primeras elecciones, transitándose a un contexto ignoto donde esa cifra se redujo hasta apenas el sesenta por ciento de los escaños, con un cincuenta por ciento de los sufragios (más de cinco millones de votos menos entre los dos principales partidos respecto de las anteriores 
elecciones). El partido más votado en esta ocasión sólo obtuvo ciento veintitrés escaños, casi cuarenta menos que la ocasión en la que hasta ese momento el partido más votado de unas elecciones había conseguido un menor número de actas (ciento cincuenta y seis en 1996). Se trata de un panorama desconocido pero que, por otro lado, no debería provocar per se turbación alguna ni asociarse indefectiblemente a inestabilidad en el seno de una democracia consolidada, no en vano resulta similar al que puede o ha podido verse en otros países con sistemas cercanos al nuestro y que no por ello han devenido, ni mucho menos, en ingobernables. Países acostumbrados a gobiernos de coalición, con una cultura de pacto arraigada y una mayor disposición al compromiso y la búsqueda de puntos de encuentro por parte de los partidos políticos y sus dirigentes, incluso entre los principales partidos, como ha podido ocurrir, por ejemplo, en Alemania con la denominada Große Koalition, la primera vez hace más de medio siglo con el Gobierno presidido por Kurt Georg Kiesinger con la alianza de la CDU y el SPD.

Así las cosas, la respuesta a la primera de las cuestiones es evidente y podría terminarse sin más, de forma escueta, esta reflexión. Debe mejorar y mucho. Regenerarse y dejar de lado la dinámica de la discordia, aunque la experiencia muestra que no parece haber mucho espacio para el optimismo. Pero este desiderátum choca de bruces con una realidad en la que no encontramos esos focos de lumbre mental que reclamaba Pérez Galdós para sanar la política (de la que fue buen conocedor como diputado reincidente), de bandos dinásticos estériles e hipócritas «sin otro móvil que tejer y destejer la jerga de sus provechos particulares en el telar burocrático».

En la práctica, como destaca el prof. Alzaga, el disenso razonable ha dejado paso al conflicto radical, y la ausencia de ese clima de consenso deriva en males para una sociedad que difícilmente pueden solventarse con instrumentos de ingeniería constitucional; quizá porque — recordando a Rokeach (The open and closed mind, 1960)— «hemos sustituido la utópica ambición platónica del gobierno de los sabios por lograr que la democracia supusiese el gobierno de los mejores, por un presente en que asistimos al esfuerzo por alistar en los partidos mentes cerradas» (Del consenso constituyente al conflicto permanente, 2011). El planteamiento ha sido muy destacado por la doctrina al amparo de este concreto traspaso de poderes que ahora analizamos; así, por ejemplo, Solozábal, abordando esta compleja permanencia en funciones, ha resaltado una idea que no pocas veces se olvida por nuestros políticos: que en el régimen parlamentario no deben caber enemigos, sino diferentes, y todo lo más, adversarios ( «La problemática constitucional de la formación del Gobierno y la intervención del monarca en nuestro régimen parlamentario», $R E D C$, 109, 2017). La situación no sólo se refleja en este proceso, sino que desgraciadamente la hemos visto en múltiples ocasiones, como ha podido acontecer con la renovación de los miembros de determinados órganos constitucionales; especialmente tensas fueron las VIII y IX Legislatura con un retraso de varios años en la renovación de los magistrados del Tribunal 
Constitucional (para la cuota del Senado) o los vocales del Consejo General del Poder Judicial.

La segunda de las cuestiones planteada en la pregunta, la posibilidad de flexibilizar el art. 99.5 CE, aunque de muy diferente tenor, no deja de llevarnos nuevamente a la primera, ya que el problema no reside ciertamente en ese artículo, como todo en la vida mejorable, sino en la suma de muchos factores, siendo el principal de todos ellos el apuntado con anterioridad: la propia responsabilidad de nuestros políticos o, mejor dicho, su ausencia en muchos de ellos. Más allá de esto, ese apartado quinto del artículo 99 - instrumento para evitar crisis prolongadas (STC 16/1984) —, que no había sido utilizado hasta el momento, y que fuera calificado tempranamente por Rubio Llorente como «bomba de relojería» («Los poderes del Estado», España, un presente para el futuro, 1984), permite concebir un bloqueo por la falta del elemento determinante del inicio del plazo a partir del cual se contarán los dos meses para procederse a la disolución caso de no obtenerse la investidura de candidato alguno. La reciente experiencia lo acredita, aunque jamás se había planteado ni como caso de laboratorio.

La Constitución es clara cuando señala que para proceder a la disolución de las Cámaras y la nueva convocatoria electoral, de cara a intentar buscar un nuevo dibujo del Congreso que permita investir un candidato, deben transcurrir dos meses desde la primera votación de investidura. Ahora bien, el problema se plantea cuando esa primera votación no llega porque el candidato propuesto por el Rey rechaza esa propuesta, como sucedió en enero de 2017, pudiendo, en su caso, llegar a una situación de bloqueo difícilmente resoluble, salvo que se proponga una nueva candidatura y ésta no sea rechazada por la persona propuesta (como finalmente ocurrió). El período no comienza a computarse sin votación, con lo que, caso de no haberse realizado nuevas consultas y aceptado el encargo otro candidato, nos hubiéramos encontrado con una coyuntura de difícil resolución a la que en su momento, y doctrinalmente, se apuntaron algunas posibilidades, ninguna de ellas completamente satisfactoria.

Aunque solventado finalmente, lo que nos puso de manifiesto esta cuestión es la existencia de un problema que no se había previsto. Las reflexiones doctrinales a lo largo de estos años en la materia se habían centrado en valorar si el Rey podía o no ampliar las consultas, su capacidad de actuación, los remedios frente a una eventual extralimitación en la presentación de candidaturas, etc. pero nada sobre este concreto punto. Ni acudir al art. 99.5 CE había sido necesario en este tiempo, ni nadie había podido imaginar este escenario. La renuncia a presentarse ante la Cámara por parte del candidato propuesto por el Jefe del Estado (Presidente del Gobierno en ese momento), no había sido puesta sobre la mesa por nadie hasta la fecha.

Al hilo de todo ello, al abrirse la espita de la reflexión, se han planteado posibles reformas o desarrollos relacionados algunos con los plazos y otros con la persona del candidato (vid. por ejemplo, Blanco Valdés, «El año que vivimos peligrosamente. Del bipartidismo imperfecto a la perfecta ingobernabilidad» y 
Revenga Sánchez, «La funcionalidad del artículo 99 de la Constitución ante el caso de un resultado electoral fragmentado», los dos en REDC, 109, 2017; Herreros López, «El Gobierno en funciones: límites y control parlamentario», Actualidad administrativa, 6, 2017; Arnaldo, «El artículo 99 CE. Hipótesis para su revisión», Satrústegui, «El artículo 99 CE supera la prueba de 2016» y Torres del Moral, «Posición del Rey en el procedimiento de investidura del Presidente del Gobierno», los tres en Lecciones constitucionales de 314 días con el Gobierno en funciones, Aranda - Coord.—, 2017).

Por lo que hace referencia a la primera de las cuestiones, se ha apuntado la posibilidad de fijar plazos para la propuesta de candidato por parte del Rey, para la intervención de dicho candidato ante la Cámara, o incluso la de reducir los tiempos para la eventual disolución automática (extremo que indudablemente exigiría la reforma de la Constitución). Con relación al segundo punto se ha planteado solventar la posible falta de candidato que acepte presentarse a la investidura asignándose esta función a la persona del Presidente en funciones, entendiendo la misma como una más de sus responsabilidades durante este tiempo.

Abordar el problema exclusivamente desde la perspectiva del plazo, bien en la fase inicial bien en la final, sin resolver la cuestión de la candidatura, poco aporta ya que nos seguiría faltando en la ecuación el dies a quo para el cómputo de los dos meses; sí parece oportuno, no obstante, quizá a través de una reforma del Reglamento del Congreso, al menos el establecimiento de un plazo máximo para que el candidato a Presidente ya propuesto por el Rey acuda ante la Cámara. Por lo que respecta a la eventual ausencia de candidato, se ha propuesto, a modo de cláusula de cierre, que corresponda al Presidente en funciones dicha obligación, mediante la reforma de la Ley del Gobierno y el Reglamento del Congreso de los Diputados (Torres del Moral, 2017). Ello podría colisionar con el art. 99 CE, al hacer obligada la propuesta del Rey, sustituyendo su voluntad, además de cargar sobre el Presidente en funciones una obligación que puede resultar políticamente impertinente en determinadas circunstancias (nos viene a la cabeza, por ejemplo, lo complejo y accidentado del traspaso de poderes en la comunidad cántabra a mediados de los noventa con inhabilitación presidencial incluida y una posterior permanencia en funciones por un período de nueve meses).

No cabe, por el contrario, como también se ha defendido, sustituir esa primera votación de investidura (coincidimos así con el criterio de Ripollés Serrano apuntado en «Rey y Presidente del Gobierno en el proceso de investidura del Presidente del Gobierno», Lecciones constitucionales.., 2017) por una mera constatación de la imposibilidad de candidatura viable alguna. Aquellos autores que sí lo han sugerido apuntaron el Dictamen del Consejo de Estado 1985/2003, emitido con ocasión de los acontecimientos que sucedieron tras las elecciones de mayo de 2003 en la Comunidad Autónoma de Madrid y que dio respuesta a las siguientes cuestiones: — «Cuándo se empieza a contar el período de dos meses legalmente previsto en el Estatuto de Autonomía y el Reglamento de la 
Asamblea de Madrid para su disolución y convocatoria de nuevas elecciones si no hay candidato a la investidura»; - «Si constituida una nueva Asamblea y antes de que transcurra el referido plazo de dos meses para que tenga lugar su disolución legal puede procederse a esta disolución por acuerdo mayoritario de la Cámara porque en el plazo de quince días no haya ningún candidato a la investidura»; - «Si transcurrido el plazo de quince días previsto en el Reglamento de la Asamblea para la presentación de candidatos a la Presidencia de la Comunidad de Madrid, sin que ninguno de ellos hubiera obtenido la confianza de la Cámara, se pueden presentar nuevos candidatos hasta que concluya el plazo legalmente previsto para la disolución de la Asamblea y la convocatoria de nuevas elecciones».

Más allá de la referencia al art. 99 CE debemos apuntar, aunque no lo abordaremos aquí por exceder el objeto de la cuestión, que al amparo de esta crisis se han planteado otras cuestiones, como la posibilidad (en absoluto neutral) de facilitar el gobierno de la lista más votada a través de la articulación de «primas de gobernabilidad» al estilo de lo que se ha establecido en otros países. También, designaciones automáticas de los candidatos de los partidos con mayor número de escaños en el caso de que en un plazo concreto ningún candidato hubiera obtenido al menos la mayoría simple de los votos emitidos, al estilo de lo previsto en alguna Comunidad Autónoma; una fórmula en todo caso en recesión, que dio origen a algunas interesantes sentencias de nuestro Alto Tribunal (SSTC 16/1984 o $15 / 2000)$ y que ya ha desaparecido de varias Comunidades que anteriormente lo recogían (incluso con la fórmula del mayor número de votos y no de escaños); y que fue objeto de severas críticas por la doctrina, como, por ejemplo, la del prof. Pérez Royo ( «Reflexiones sobre la contribución de la jurisprudencia constitucional a la construcción del Estado autonómico», REP, 49, 1986), que tempranamente sostuvo su dudosa constitucionalidad sobre la base de que «la racionalización» del sistema parlamentario es posible siempre que se respete el principio básico sobre el que se eleva», y «si no es posible no preguntar a la Asamblea, tampoco puede serlo preguntarle, y cuando dice no, actuar como si no lo hubiera dicho».

Cabe recordar, por último, que durante la tramitación constituyente se planteó, aunque sin recabar el suficiente apoyo, la posibilidad de un Gobierno de gestión o transición creado ad hoc en el caso de una disolución por el fracaso del proceso de investidura. Así, en el Senado se presentó una enmienda que pretendía para el supuesto de que se produjese la disolución de las cámaras por haberse agotados los plazos sin que candidato alguno hubiese obtenido la confianza, se procediese al nombramiento de un Gobierno de transición encargado de la realización de las elecciones ( $« \mathrm{Si}$ en el plazo de un mes a partir de la primera votación de investidura, ningún candidato hubiere obtenido la confianza del Congreso, el Rey previa consulta con los representantes de los grupos políticos, designará el Presidente del Gobierno y disolverá y convocará nuevas elecciones. El decreto de nombramiento del Presidente así como el decreto de disolución y convocatoria de 
nuevas elecciones serán simultáneos y serán refrendados por el Presidente del Congreso»). No parece que esta solución hubiera tenido más ventajas que inconvenientes y creemos que fue un acierto del constituyente su no incorporación. Mucho más operativa resultó la opción elegida, con la articulación de un Gobierno en funciones y la conjunción del control parlamentario con todos aquellos controles que a la actuación de aquél se le pueda oponer.

\section{JOSEFA RIDAURA MARTÍNEZ}

La respuesta a la primera cuestión, ineludiblemente, ha de ser afirmativa. Ciertamente, el comportamiento del Gobierno y de los dirigentes de los partidos políticos con representación parlamentaria durante el prolongado período de interinidad gubernamental ha revelado su dificultad para solventar una situación nada habitual y anómala en nuestra reciente historia constitucional.

En efecto, las Cortes que se constituyen tras las elecciones de diciembre de 2015 y junio de 2016 se han enfrentado a una transformación en la tradicional composición y configuración de las Cámaras; debiendo acomodarse a una nueva realidad caracterizada por un acrecentamiento de la fragmentación parlamentaria. Y, aunque el Parlamento español siempre ha estado fragmentado, hasta ahora, ello no había sido obstáculo para conseguir mayorías (absolutas o relativas) lo suficientemente holgadas para la formación de Gobierno. Bien en primera, bien en segunda vuelta, se había ido produciendo la alternancia entre las dos fuerzas políticas mayoritarias (PP-PSOE), con ocasionales acuerdos con otras fuerzas parlamentarias, que cuantitativamente no ponían en riesgo la estabilidad de un bipartidismo imperfecto, ya que los pactos puntuales (no por ello carentes de relevancia) señaladamente con las fuerzas nacionalistas, nunca habían obstaculizado investiduras presidenciales. Así pues, desde que comienza la andadura de la Constitución del 78, nuestro parlamentarismo se ha caracterizado por unas Cámaras con fuerte presencia de partidos políticos y grupos parlamentarios, pero con una prolongada estabilidad gubernamental. Constituyendo, hasta cierto punto, una anomalía en el marco europeo, ya que España es el único país que tiene un sistema electoral proporcional que no ha tenido gobiernos de coalición.

Tras los últimos comicios, hemos asistido, no a una irrupción de la fragmentación, sino a un incremento sustancial de ésta, dificultando la consecución de mayorías suficientes para formar un gobierno estable. El equilibrio sostenido entre dos fuerzas políticas mayoritarias se ha visto tambaleado por la entrada en la arena parlamentaria de dos fuerzas políticas (Ciudadanos y Podemos) que, en las primeras elecciones de diciembre de 2015, han sumado entre ambas 109 de los 350 escaños.

La conformación de unas Cámaras renovadas, ha permitido vislumbrar que los responsables políticos han afrontado con dificultad esta nueva situación. Unas élites políticas que estaban acostumbradas a un modo de operar, forjado sobre la 
solidez de los dos grupos mayoritarios, ha generado unas dinámicas de actuación que ahora ya no valen, ni para conseguir holgadamente investiduras, ni, tampoco, para desarrollar programas de gobierno sin apuros.

En definitiva, esta nueva realidad ha sacado a la luz la punta del iceberg: unas élites más preocupadas por priorizar las estrategias de partido que los intereses generales; $y$, sobre todo, poco curtidas en el pacto.

En relación con la segunda cuestión planteada, no creo que estemos ante un problema de plazos, sino de responsabilidad de las élites políticas. Esto es, los problemas que ha planteado la reciente investidura del Presidente del Gobierno no se resuelven tanto jurídicamente, como políticamente, mediante la asunción de responsabilidades en atención a la ética que demanda la lealtad institucional.

El art. 99 de la Constitución reguló un novedoso procedimiento de investidura presidencial sin precedentes en el constitucionalismo histórico español; que, además, contrasta con la parquedad de otros textos constitucionales (alemán e italiano, por ejemplo). Su diseño nos parece loable. Es verdad que el artículo estableció unas extremadas cautelas, que durante muchos años nos permitieron explicarlo como un "precepto de laboratorio». Siempre habíamos pensado que nunca se llegaría a aplicar en todos sus extremos. Pero, tras los recientes acontecimientos, el proceso de investidura, tal y como está regulado en el texto constitucional, nos plantea serie de consideraciones:

En primer lugar, en orden a la flexibilización de los plazos, el art. 99.5 establece el de dos meses, a partir de la primera votación de investidura, para que un candidato a la Presidencia del Gobierno alcance la confianza del Congreso, transcurrido el cual sin que ésta se haya logrado, el Rey disolverá ambas Cámaras y convocará, con el refrendo del Presidente de las Cortes, nuevas elecciones.

Flexibilizar este plazo no parece la solución idónea; y ello por varias razones: primero porque no resulta conveniente mantener a un Gobierno en funciones durante mucho tiempo, pues impide el normal desenvolvimiento de la actividad política del Estado, con consecuencias importantes; pese a que se haya aportado ejemplos como el de Bélgica, en el que la interinidad del Gobierno durante 541 (entre 2010 y 2011) se calificó positivamente en atención a los resultados obtenidos. En todo caso, me parece un ejemplo circunstancial, que no puede elevarse a categoría general. Por el contrario, relajar el plazo permite a los responsables políticos acomodarse, sin premuras, a una situación de interinidad, mientras que se ralentizan políticas públicas por la imposibilidad de aprobar nuevos Presupuestos Generales, por poner sólo un ejemplo.

Es más, también el Tribunal Constitucional ha sostenido que el principio de racionalización de la forma parlamentaria de gobierno trata de impedir, entre otros objetivos, las crisis gubernamentales prolongadas, y a este fin es al que responde la disolución automática de las Cámaras cuando se evidencia la imposibilidad de designar un Presidente de Gobierno dentro del plazo constitucional.

Pero, si la virtualidad de esta ampliación está en facilitar un pacto de gobierno, ello exige una lealtad institucional por parte de todos los responsables 
políticos. Nuestras élites políticas deberán acomodarse a la nueva situación descrita con anterioridad, con unas Cámaras más fraccionadas, y con un creciente peso del Parlamento frente a la arraigada preeminencia del Ejecutivo, para alcanzar, bien gobiernos de coalición, bien pactos de legislatura. Y, para ello no es necesario ampliar plazos, sino cambiar comportamientos políticos, que se sustenten, esencialmente, en la responsabilidad y en la lealtad constitucional.

Segundo, porque flexibilizar el plazo para adelantar los comicios electorales tampoco parece muy conveniente. Convocar elecciones en un plazo inferior al estipulado en el artículo 99.5 redundaría muy negativamente en una ciudadanía, que asistiría, repetidamente y en un lapso muy corto, a tener que resolver lo que sus representantes políticos no han podido remediar mediante el acuerdo; acrecentándose la brecha entre sociedad civil y responsables políticos.

La argumentación para mantener los dos meses establecidos en el art. 99.5 que lleva a cabo el Consejo de Estado (Dictamen 1985/2003, de 26 de junio), habida cuenta del paralelismo que guarda el caso planteado con el precepto constitucional, nos parece certera. Resalta, así, la finalidad de dicho plazo en orden a gozar de un periodo de sosiego, reflexión, negociaciones, acuerdos; todo antes de llegar a la solución más extrema de disolución, que sólo entra en juego cuando «se hayan explorado e intentado sin éxito todas las posibilidades que el sistema parlamentario brinda en conexión, naturalmente, con las circunstancias de la situación (el llamado «diálogo» entre los hechos y el Derecho)».

En sentido similar, la sugerencia de no agotar los dos meses cuando el Monarca pueda advertir que, acercándose el vencimiento del plazo, no pueda proponer un candidato con expectativas razonables de obtener la confianza parlamentaria no es jurídicamente posible. La disolución de las Cortes en este supuesto concreto no está prevista constitucionalmente. Para ello debería reformarse el texto constitucional, pero no consideramos pertinente esta concreta reforma por las razones apuntadas.

La única reforma aconsejable en este orden de consideraciones sería aclarar debidamente el cómputo de los plazos; pero ya lo hace el Reglamento del Congreso cuando establece que transcurridos dos meses a partir de la primera votación de investidura, si ningún candidato propuesto hubiere obtenido la confianza del Congreso, el Presidente de la Cámara someterá a la firma del Rey el Decreto de disolución de las Cortes Generales y de convocatoria de elecciones, y lo comunicará al Presidente del Senado (art. 172.2 RCD). Es, pues, la primera votación la que marca el inicio del cómputo del plazo de los dos meses, despejándose así dudas acerca de soslayar las propuestas regias de candidatos.

En segundo lugar, se ha venido proponiendo un procedimiento subsidiario y extraordinario por medio del cual, al no haberse alcanzado en la Cámara una mayoría suficiente en torno a alguno de los candidatos propuestos, el Rey proponga el nombramiento del candidato del grupo mayoritario, de forma que sea la voluntad del cuerpo electoral, manifestada en el número de escaños o, en caso de empate, en el mayor número de votos la que resuelva el bloqueo. Se trata de una 
solución adoptada por algunas Comunidades Autónomas, (Ley Foral de Navarra 9/1991, de 16 de marzo, y similarmente los Estatutos de las Comunidades Autónomas de Andalucía y Castilla-La Mancha), y acerca de la que el Tribunal Constitucional ha manifestado que, en ese caso, no deba suponer que se prescinda de los elementos y principios que informan todo el sistema, esto es, la referencia continua a la voluntad popular (STC 15/2000). Esta solución puede resolver la votación de investidura y la formación posterior de gobierno; pero no resuelve del todo el problema pro futuro, ya que el grupo que consiga formar gobierno tiene que sacar adelante su programa con mayorías muy ajustadas.

En todo caso, esta propuesta exigiría la reforma constitucional. Al igual que la solución adoptada en algunos Estados en los que, ante la imposibilidad de elección del presidente, se forme un gobierno de coalición; para ello en España, como hemos visto, han de cambiar mucho los comportamientos políticos.

En tercer, y último lugar, la previsión de disolución de las Cámaras, que acarrea también la del Senado, no me parece afortunada. Sobre todo porque la Cámara alta no ha tenido ninguna participación en la investidura, y, sin embargo, también es disuelta. Llama la atención que esta previsión se planteara en el Seno de la Comisión mixta Congreso-Senado durante la elaboración de la Constitución.

\section{MARÍA ESTHER SEIJAS VILLADANGOS}

Durante los más de 300 días de Gobierno en funciones los medios de comunicación elevaron públicamente un sentir común reflejado en los mensajes lacónicos de los distintos editoriales: responsabilidad, perversión de la política, cuidado con los plazos...

Dos son los frentes a analizar: uno inmaterial, vertebrado en torno a lo que se ha denominado como «cultura política», y otro material, preciso o precisable, como es la regulación temporal del proceso de formación de Gobiernos. Ambos se determinan mutuamente, requiriendo un avance parejo para poder aportar alguna luz a este túnel en el que parece que nos vamos a instalar.

Nuestro sistema parlamentario se ha erigido sobre un conjunto normativo, que no está de más recordar es preceptivo, y sobre un entramado de presupuestos y pautas de funcionamiento no escritas, pero esenciales, a las que podemos referirnos en términos genéricos como «cultura política», de la que desglosaríamos la especie «cultura constitucional».

Esta cultura política aludiría a la capacidad de los actores políticos de compatibilizar sus posiciones antagónicas o diferenciadas con el funcionamiento estable y eficaz de las instituciones. Su naturaleza se sustenta en dos presupuestos: por un lado, la necesaria legitimidad con que un sistema político ha de configurarse (Schmitt, 1932) y, por otro, la imprescindible proyección eficaz del mismo (Bagehot, 1867), esa parte eficiente que permite a los ciudadanos abrazar resultados y consecuencias. En un Estado constitucional, dicha cultura política se transforma 
en «cultura constitucional» (Häberle, 1982). La Constitución no es sólo un texto jurídico, sino que es un agente de desarrollo cultural, resultado material del pluralismo, valor superior de nuestro ordenamiento jurídico. Esta cultura constitucional ha de interiorizarse por los ciudadanos y, desde luego, por nuestros representantes. Sus manifestaciones más ilustrativas las podríamos referir a la presencia de una ética política del respeto, a una solución dialogada de los conflictos, a una especial habilidad, cualificación y ejemplaridad de los líderes o a una contribución positiva en la formación y funcionamiento de las potenciales coaliciones. Un alejamiento de estas prácticas sería una desconstitucionalización de nuestro sistema político. Este contexto es propicio para postular una reformulación de la teoría de las élites, partiendo de asumir su inevitabilidad (Mosca,1923), se convierte en imperativo reivindicar su designación por sus cualidades excepcionales y por sus competencias dentro de esa cultura constitucional y denunciar que su designación obedezca al único hecho de situarse en las estructuras que les catapultan a ello (Michels, 1936). Esta reflexión es válida tanto para los políticos tradicionales, como para los no tradicionales pero con éxito electoral (particularmente para los outsiders) y tanto para el ámbito nacional, como para el internacional. No consuela demasiado que este mal sea un mal de muchos. La alerta weberiana de la distinción entre vivir de la política y vivir para la política (El politico y el científico) encuentra en estos momentos de tensión institucional su mejor acomodo.

En lo que concierne al segundo de los aspectos, el temporal, el test de estrés al que se ha sometido el artículo $99 \mathrm{CE}$ ha probado su manifiesta mejorabilidad. Empero, cualquier revisión del mismo tiene que atender a un objetivo: facilitar la formación de un Gobierno tras unas elecciones, evitando su repetición inmediata, esto es acortando lo más posible la incierta duración de la interinidad del Gobierno en funciones. Una vez que los ciudadanos se han manifestado, el fallo de la ecuación está en la incapacidad para transformar esas propuestas cuantitativas en una fórmula cualitativa, no en quienes ya han votado y se les obliga a repensar si mantener el sentido de su voto — a sabiendas de las consecuencias déjà $v u$ de mantenerlo_- o si afrontar un viraje maximizando ora el voto útil, ora el voto de castigo e incluso abrazar la desesperada opción de dejar al azar el destino de la opción elegida.

En la implementación del art. 99 podemos referenciar una secuencia concatenada de ítems: la convocatoria y celebración de elecciones; la constitución del Congreso; las consultas con los representantes designados por los Grupos políticos con representación parlamentaria — facultativa para dichos grupos-; la propuesta de un candidato o la ausencia de la misma; la solicitud de la confianza de la Cámara y la votación, primero por mayoría absoluta y, tras cuarenta y ocho horas, por mayoría simple; la sucesión de propuestas en el caso de fracasar las formuladas; la disolución de ambas cámaras transcurridos dos meses, si los candidatos hubieran fracasado en obtener la confianza de la Cámara. Si atendemos a las dos lagunas señaladas, quienes decidan no acudir a la primera ronda de consultas, 
cuyo contenido podría vincularse a un protocolo objetivo de verificación de posiciones, tendrían que ser excluidos de las consultas sucesivas. Este comportamiento troyano, de integrarse en el sistema para luego dinamitarlo, es meridianamente reprobable a la par que insultantemente incoherente. La segunda, la que más quebraderos de cabeza ha supuesto, relativa a la ausencia de postulantes y generadora de un bloqueo jurídico era políticamente inconcebible. Un esperpento valleinclanesco, según el cual me presento ante los ciudadanos como candidato a presidente del Gobierno, pero no me presento ante sus representantes. Suscribo la postura de Torres del Moral, (2016) defendiendo la necesidad de salvar este obstáculo desde quien tiene la obligación de contribuir a la formación del nuevo Gobierno, es decir del presidente del Gobierno en funciones, tanto si éste ya no ha concurrido a las elecciones y no ostenta acta de diputado, como cuando en él confluye este estatus y el de líder de la formación con más escaños en el nuevo legislativo. A este respecto conviene traer a colación que la Exposición de motivos de la Ley 50/1997 enfatiza que la regulación del Gobierno en funciones, una de las principales novedades de dicha ley, se basa «en el principio de lealtad constitucional, delimitando su propia posición constitucional y entendiendo que el objetivo último de toda su actuación radica en la consecución de un normal desarrollo del proceso de formación del nuevo Gobierno». En esa contribución a la normalidad institucional se justificaría tal propuesta. Una opción más radical implicaría optar por un giro mayoritario de nuestro sistema electoral, habilitando una segunda vuelta en sede parlamentaria, donde la presentación de propuestas se reduzca a dos, las más votadas, y que se presentarían de modo sincrónico.

Para el resto del proceso, asumiendo su escasa operatividad si no va aparejado de la interiorización de la cultura constitucional de nuestras élites, una propuesta implicaría:

El transcurso de un mes desde la celebración de elecciones hasta el desarrollo de las consultas. Veinticinco días hasta la constitución del Congreso, máximo posible, y cinco días hábiles inmediatos a su constitución para desarrollar la primera ronda de consultas, sin dejar esta posibilidad al albur de la voluntad del monarca. Esta fase podría reproducir un cuestionario idéntico a cada representante desde el que se trazaría el mapa negociador, siempre en supuestos de parlamento fragmentado.

Un segundo mes para convocar la segunda ronda de consultas. A ella los representantes ya deberían llevar una propuesta de configuración de Gobierno, ya sea en coalición o en minoría, con los apoyos comprometidos. Tras dichas consultas, un plazo no mayor a una semana para presentar la propuesta de candidatura al Congreso y desarrollarse la primera votación.

A partir de ahí, un plazo de dos meses — por lo que no sería necesario reformar la Constitución - para presentar y votar las sucesivas propuestas. Es decir, abogamos por una flexibilización del plazo, pero ex ante, apostando por un período 
de intensas negociaciones previo al plazo preclusivo de los dos meses tras la presentación de la primera candidatura.

Si hubiera que afrontar una reforma constitucional, nuestra preferencia sería eliminar la conexión del artículo 99. 5 CE y el 115. 3 CE, limitando a un año el período para repetir las elecciones, so pena de utilizar ese recurso para estimular la formación de un Gobierno y no para estandarizar a un año la duración del Gobierno en funciones.

2. A la vista de las experiencias recientes, ¿Qué opinión nos puede dar sobre el papel del Rey en su propuesta al Congreso de los Diputados de candidato a Presidente del Gobierno? 'Cree que el refrendo por el Presidente del Congreso debe ser entendido de forma que no deje ningún margen de impulso al Rey? 'A Aén de la consulta con los representantes designados por los Grupos políticos con representación parlamentaria, tendría sentido que el Rey tuviera la prerrogativa de escuchar a algún informador, en forma similar a como se opera en la monarquía bolandesa?

\section{JAVIER GARCIA FERNANDEZ}

A lo largo de 2016 tuve ocasión de publicar algunos artículos en prensa en donde traté de perfilar jurídicamente el papel del Rey (por ejemplo, «Mitos sobre la investidura», El País, 2 de enero de 2016; y «La tarea del Rey», El País, 17 de febrero de 2016). A mi juicio, el Rey no encarga formar Gobierno ni tampoco selecciona al Presidente. El Rey tiene como misión discernir, a partir de las entrevistas con los dirigentes políticos designados por los partidos, quien tiene posibilidades de obtener la investidura del Congreso. Tiene algo de notario que da fe del panorama parlamentario a partir de la información proporcionada por los representantes de los partidos. Por eso es tan importante, como he indicado en la respuesta a la primera pregunta, que los partidos lleguen a la entrevista con «los deberes hechos», es decir, habiendo negociado los eventuales apoyos. Quiere ello decir que no estamos, como han dicho algunos autores, ante una expresión de Poder Arbitral y Moderador: no hay nada que arbitrar ni moderar porque ello comportaría otorgar un margen discrecional al Rey que no puede poseer porque sólo tiene legitimidad histórica (tradicional, que diría Weber) y democrática (sobre ello ya me he pronunciado en "Arbitra y modera el funcionamiento regular de las instituciones...'. Reflexiones sobre la función arbitral y moderadora del Monarca ante una eventual reforma constitucional», en Memorial para la reforma del Estado. Estudios en homenaje al Profesor Santiago Muñoz Machado, Centro de Estudios Políticos y Constitucionales, Madrid, 2016, t. I, págs. 517-531). A mí me parece una fórmula constitucional acertada para una Monarquía parlamentaria donde el Jefe del Estado no debe entrar en el juego de los partidos. 
La segunda parte de esta pregunta, acerca del carácter del refrendo que otorga el Presidente del Congreso a la propuesta del Monarca y si debe ser entendido de forma que no deje ningún margen de impulso al Rey, debe responderse, a mi modo de ver, en el sentido de que, desde el punto de vista jurídico-formal, el Rey no tiene capacidad de impulso: toma nota de la información que le proporcionan los representantes de los grupos políticos con representación parlamentaria y si cree que hay alguna persona con capacidad de presentarse como candidato ante el Congreso, lo propone. Y si no hay ese posible candidato, no lo propone. Pero esto enlaza con la tercera parte de la pregunta, como veremos a continuación.

Se plantea si amén de la consulta con los representantes designados por los Grupos políticos con representación parlamentaria, tendría sentido que el Rey tuviera la prerrogativa de escuchar a algún informador, en forma similar a como se opera en la monarquía holandesa. Creo que la respuesta ha de ofrecer muchos matices. En primer lugar, nada impide que el Rey, a título informal, hable y se asesore con otras personas durante el proceso de formación del Gobierno. Pero esas conversaciones, ese asesoramiento, no puede tener carácter formal porque entraría en el campo formalizado delimitado en el artículo 99.1 de la Constitución. Eso no sería una consulta (preceptiva) cuya función se debe preservar porque asegura que el Rey se relacione con todos los grupos políticos representados en el Congreso (otra cosa es que haya grupos de dudosa calidad democrática que no quieran acudir). De modo que debemos preservar la naturaleza jurídicamente formalizada de la consulta pero en una situación complicada (como fue la que llevó a celebrar elecciones en junio de 2016) nada impide que el Rey hable discretamente, por ejemplo, con Presidentes prestigiosos y asentados como Felipe González y José María Aznar. Y esto nos conduce al tema del informador.

$\mathrm{El}$ informador es una figura que los constitucionalistas neerlandeses alaban (por ejemplo, entre otros, Leonard F. M. Besselink: Constitutional Law of the Netherlands, Ars Aequi Libri, Nimega, 2004, págs. 29-33) pero cuanto más se analizan las figuras (que hay dos) del informateur y del formateur (en francés ambos términos) se ve la dificultad de aplicarlo a España pues la Constitución de los Países Bajos, como todas las Constituciones decimonónicas (y la neerlandesa lo es a pesar de sus reformas), no regula apenas la elección del Primer Ministro y da un margen a las convenciones que vienen del siglo XIX. Pero vistas las diversas interpretaciones que se dio a cada acto del Rey en el proceso de formación del Gobierno a comienzos de 2016, creo que es preferible no acudir a una figura extraña a nuestra práctica que provocaría bastantes suspicacias respeto a su neutralidad.

\section{ÁNGEL J. GÓMEZ MONTORO}

En mi opinión, el Rey ha actuado impecablemente en el largo y complicado proceso que vivimos el año pasado y pienso que su papel no debe ir más allá. Como he señalado en la pregunta anterior, creo que los problemas que hemos 
vivido no se derivan de la regulación constitucional sino de la actitud de las fuerzas políticas. Y en ese contexto, me temo que dar mayor protagonismo al Rey no ayudaría significativamente a resolver las crisis políticas y sí vendría a añadir un elemento de desgaste de la propia Monarquía que no sería positivo para nadie. Entiendo que, si por tratarse de una situación especialmente complicada, hiciera falta una mayor labor de impulso político, esta debería ser asumida, con la debida prudencia e imparcialidad, por el Presidente del Congreso que, al fin y al cabo, es quien refrenda y por tanto responde. Si, como cabe esperar, quien ocupa ese puesto tiene la suficiente auctoritas y actúa con neutralidad, está en mejores condiciones de asumir esa labor de mediación.

En cuanto a la posibilidad de que el Rey consulte con algún informador, creo que nada lo impide y que no sería extraño que, de hecho, el Monarca consultase con personas de su confianza. Lo que entiendo que se plantea en la pregunta sería más bien si esas posibles consultas no deberían ser informales sino con la misma publicidad y trasparencia que cuando recibe a los representantes de los grupos parlamentarios. No veo ningún problema en que algo así pudiera hacerse, pero dudo mucho de su eficacia y me temo que incluso podría generar mayor ruido mediático, si se me permite la expresión.

\section{JOSÉ ANTONIO MONTILLA MARTOS}

Es bien conocido que algunos autores han defendido un papel activo del Rey al hacer la propuesta de candidato del artículo 99.1 CE, derivado del artículo 56.1 CE según el cual el Rey arbitra y modera el funcionamiento regular de las instituciones. De esta forma, se ha dicho que podría implicarse en las negociaciones entre los distintos partidos para que alcancen un acuerdo, proponer un candidato independiente al margen de los partidos o incluso valerse de un mediador para buscar el acuerdo.

No comparto esa posición. A mi juicio, el Rey debe limitarse a la función transmisora y estrictamente formal. Debe ser, utilizando la expresión de Miguel Revenga, un «activador mecánico de las distintas fases del proceso»: consulta a los representantes de los grupos políticos, propone candidato y nombra presidente de Gobierno, en los dos últimos casos con el refrendo del Presidente del Congreso.

Así lo ha hecho en líneas generales Felipe VI en la primera ocasión en que le ha correspondido actuar que no ha sido, ni mucho menos, la más fácil. A mi juicio, en todo este proceso el Rey ha cumplido su función constitucional con pulcritud. Tras las elecciones de 2015, celebró tres rondas de consultas. Después de la primera no hizo propuesta de candidato ante el rechazo de Rajoy a ser propuesto, reflejando en todo caso en el comunicado emitido que había hecho ese ofrecimiento y había sido declinado. Después de la segunda ronda, propuso al candidato del PSOE, Sánchez, que expresó su voluntad de someterse a la 
investidura, finalmente fracasada. Luego hizo una tercera ronda de consultas antes de la disolución automática al transcurrir dos meses desde esa primera votación de investidura para constatar que ningún candidato estaba dispuesto a someterse a la investidura. En definitiva, cuando el líder del grupo con mayor número de diputados ha declinado el ofrecimiento para ser propuesto, el Rey no ha hecho dicha propuesta, y cuando el líder del segundo partido le ha planteado que quería intentar ser investido ha hecho efectivamente esa propuesta. Luego, tras las elecciones de 26 de junio, celebró una primera ronda de consultas tras la que propuso a Rajoy como candidato, que no resultó investido, y, luego, un mes después realizó una nueva ronda y volvió a proponer a Rajoy, finalmente investido. Aquí he advertido la única extralimitación del Rey, siquiera menor, en todo este proceso cuando tras la primera votación de investidura exhorta al acuerdo político en su comunicado, en concreto a «una forma de ejercer la política basada en el diálogo, la concertación y el compromiso».

Si sostenemos que el Rey debe limitarse a ser el activador mecánico del proceso y otorgarle el reconocimiento formal a los distintos actos no sólo es porque otra forma de actuar podría suponer un riesgo para la monarquía en cuanto la sitúa en el debate político. La razón es más importante. El Rey no puede desarrollar una actividad política en el proceso de formación del gobierno porque carece de legitimidad democrática. Por ello, no puede atribuirse poder político alguno, siquiera en supuestos excepcionales de inexistencia de acuerdo para la formación de gobierno. Esa es una diferencia fundamental entre nuestro jefe de Estado y el de Alemania o el de Italia que en ambos casos tienen un mayor margen de maniobra para facilitar la formación del gobierno. En esos casos tienen una legitimación democrática siquiera indirecta de la que carece el monarca. Por ello, puede tener sentido que esos jefes de Estado realicen una labor de búsqueda de un candidato de consenso. Sin embargo, el español debe evitar cualquier actuación con un atisbo de contenido político y ceñirse a lo simbólico-formal.

Se ha planteado, por último, la cuestión de si el Presidente del Congreso puede realizar esa tarea de búsqueda de un candidato para trasladar ese nombre al Rey, en cuanto la propuesta que éste haga debe tener el refrendo del Presidente del Congreso, que asume la responsabilidad. Sin embargo, no debemos olvidar que el Presidente del Congreso no es neutral, pese a su función institucional, sino un diputado de un determinado grupo parlamentario.

\section{MIGUEL REVENGA SANCHEZ}

La crisis de 2016 y la aplicación de las previsiones constitucionales hasta por dos veces en una tesitura además inaugural para la persona del rey Felipe VI, ha enriquecido notablemente la praxis constitucional de la monarquía parlamentaria y lo ha hecho de una manera en la que nuestra forma de gobierno, me parece, sale fortalecida. La gran novedad de las cinco rondas de consultas celebradas por 
el rey entre los meses de enero y octubre de 2016 es que el rey, por medio de su Casa, se ha expresado ante la opinión pública por medio de Comunicados que dejaron traslucir el entendimiento que albergaba el monarca sobre las consultas y la razón de ser de las mismas. Lo que se deduce de esos Comunicados, en términos generales, es que las consultas no son, en modo alguno, una plataforma o un foro concebido para que el rey pueda desplegar unas hipotéticas capacidades de influjo sobre el logro de acuerdos entre las fuerzas políticas de cara a la investidura, sino el modo de solemnizar la transmisión al rey de los puntos de vista de cada una de ellas para un correcto ejercicio por su parte de la facultad de proponer candidato o, en su caso, de la decisión de aplazar la propuesta. En un contexto en el que la gestión de los tiempos resulta esencial, si algo ha quedado claro, es que el rey ha reivindicado su papel como activador del funcionamiento regular de las instituciones, que es la función que le atribuye el artículo 56 de la Constitución, si bien encadenándola con dos verbos — arbitrar y moderar - que tienen un significado bastante más equívoco que el del término «activador» que nosotros acabamos de utilizar. Ciertamente en la tesitura resultante de las elecciones de diciembre de 2015, resulta algo «chocante» que el Comunicado de 22 de enero de 2016 diera cuenta de una renuncia de Mario Rajoy a ser candidato, previo agradecimiento a Su Majestad el Rey (sic) del ofrecimiento de serlo. Seguramente en ello influyó el deseo del rey de tomar distancia con respecto a un desenlace de las consultas en el que, por vez primera en nuestra práctica constitucional, no iba a haber candidato, pero con independencia de ello, creo que el rey sí tuvo margen de decisión para determinar las fechas de las consultas y, en consecuencia, ello podría haberse convertido - y así lo interpretamos «pro futuro»— en un importante factor condicionante del desarrollo del proceso de formación de Gobierno; no porque el margen de maniobra sobre los tiempos permita influir en el desenlace «sustancial», es decir, en el signo de este o aquel Gobierno en detrimento del otro, sino porque permite dilatar la activación del plazo que lleva a la disolución. Por supuesto que se trata de un ámbito de decisión que el rey no puede ejercitar con independencia de (y mucho menos en contraposición a) la opinión que acerca de ello pueda tener la presidencia del Congreso, puesto que, en nuestro criterio, el significado constitucional del refrendo es en el fondo unívoco y no debería dejar margen para un fraccionamiento de la categoría en especies diversas según cuál sea el peso del refrendante en el contenido de la decisión refrendada. El cuándo de las consultas, pero sobre todo el cuándo y el contenido de la propuesta de candidato es un asunto cuyo tenor comparten refrendante y refrendado; y en qué condiciones y con arreglo a qué criterios es cuestión que queda bajo la reserva y el sentido de la discreción que con respecto al mismo quieran mantener uno y otro. El enfrentamiento abierto o la disparidad irresoluble de criterios en este ámbito equivaldría, lisa y llanamente, a una crisis constitucional que comprometería la subsistencia del sistema. Por lo que se refiere al posible nombramiento de un «informador» o una figura equivalente al modo holandés — donde por cierto en el momento de escribir estas líneas han transcurrido ya tres meses en el intento 
de formar Gobierno - creo que no añadiría ninguna mejora sustancial al diseño que ya tenemos en la Constitución. El papel de «formador»o «informador» lo desempeña entre nosotros, con todas las ventajas y servidumbres propias del cargo, la presidencia del Congreso.

\section{FERNANDO REVIRIEGO PICÓN}

Son múltiples las formas de nombramiento o designación del Presidente del Gobierno que nos ofrece el Derecho comparado, fórmulas que exponencialmente se multiplican cuando acudimos además a los diferentes contextos históricos; una consecuencia más de la transformación de los usos políticos que de las propias estructuras constitucionales, como refirió Blondel (An Introduction to Comparative Government, 1969).

Dentro de los regímenes parlamentarios la diferencia principal la encontramos entre aquellos ordenamientos que prescriben una necesaria manifestación expresa por parte de las cámaras, y los que permiten la instauración del vínculo fiduciario sin esa exigencia, presumiéndose la confianza salvo voto en contrario, lo que se categorizó como parlamentarismo negativo (vid. Fusilier, Les Monarchies Parlementaires, 1960). En éstos últimos, solo a través de esa hipotética condición resolutiva del voto de desconfianza podrá romperse el vínculo fiduciario que hasta ese hipotético momento se entiende instaurado (el fundamento de esta confianza se encontraría de esta manera basado en una presunción y no tanto en una positiva actitud por parte de la cámara o cámaras, ya que no se manifiestan en ese previo momento referido — Lavaux, Parlementarisme rationalisé et stabilité du pouvoir exécutif, 1988-; la «responsabilidad política condicionada» de la que nos hablara Sánchez Agesta — «Gobierno y responsabilidad», REP, 113/114, 1960—). En consecuencia, modelos de confianza expresa vs. modelos de confianza presunta o implícita.

Para los primeros luego habrá que tener en cuenta cuestiones procedimentales de muy diverso tenor, como las mayorías exigidas, el requerimiento o no de un programa de gobierno, la posibilidad de investiduras de candidato o del conjunto del gobierno, la participación de una o dos cámaras, la articulación de eventuales investiduras automáticas, bien absolutas y directas o relativas e indirectas, etc.

En el caso español, el constituyente prescribió, en el minucioso art. 99 CE, la obligatoriedad de la verificación de consultas por parte del Jefe del Estado con los representantes designados por los grupos políticos con representación parlamentaria, independientemente de los concretos resultados que se hubieran podido producir: «Después de cada renovación del Congreso de los Diputados, y en los demás supuestos constitucionales en que así proceda, el Rey, previa consulta con los representantes designados por los grupos políticos con 
representación parlamentaria, y a través del Presidente del Congreso, propondrá un candidato a la Presidencia del Gobierno».

Ello nos diferencia de otras Monarquías parlamentarias, como la belga, la danesa, o la holandesa, donde se recurría a la figura de los «formadores» o «informadores» - figura que también habría existido en la Francia de la IV República-, que no sólo se encargaría de suministrar los datos al Jefe del Estado, sino que igualmente podría proceder a negociar de alguna forma entre las diferentes fuerzas, y que incluso, llegado el caso, podría convertirse él mismo en candidato - entre la amplia bibliografía existente, vid. a título de ejemplo, Miller (Government and Politics in Denmark, 1968), Waleffe (Le Roi nomme et revoque ses ministers, 1971), Colliard (Les régimes parlementaires contemporains, 1978) o Molitor (La fonction royale en Belgique, 1979)_. Más allá de la nomenclatura, la experiencia en esos países apuntados muestra que han existido tanto informadores que han terminado por dirigir el Gobierno, como formadores que no han entrado finalmente en los mismos.

No resulta extraño que en estos y otros países se haga una interpretación amplia de las consultas, celebrándose por parte del Jefe del Estado (se trate o no de una Monarquía) no solo con las personas que tienen una directa intervención en el posterior otorgamiento de la confianza, sino igualmente con otras por el carácter supra partes que tendrían dentro del juego político (en algunos países estas consultas se han verificado con expresiones tan ambiguas como la de ciudadanos conocidos por su honorabilidad y capacidad); una forma de tratar de resolver situaciones problemáticas que en concretos momentos pueden generarse. No obstante, y a la vista de la práctica comparada, lo cierto es que algunas consultas resultan ciertamente singulares, como podrían ser por ejemplo algunas de las realizadas en Italia en determinados momentos (el Jefe de Estado se terminó entrevistando en diferentes ocasiones con el Gobernador de la Banca Italiana, el Comandante de los carabineros o el Vicepresidente del IRI, por citar algunos, Zagrebelsky, «La formazione del Governo nelle prime quatro legislature repubblicane», RTDP, 1968; vid. también Paladin, «Governo italiano», Enciclopedia del Diritto, 1970, Vignochi, Guetti, Corso di Diritto pubblico, 1984-).

Por lo que hace referencia a nuestro sistema político, no parece que la actuación del Jefe del Estado en la propuesta de candidato a Presidente del Gobierno deba ir más allá de su carácter meramente simbólico y protocolario. No compartimos las opiniones que, durante la Legislatura fallida (XI, en la que se celebraron hasta tres rondas de consultas) y la actual (XII, en la que se realizaron dos más), abogaron por concederle un mayor relieve y capacidad de acción en su intervención. Su papel debe ser el de mera ratificación de los acuerdos alcanzados (o, en su caso, no alcanzados) y prefigurados por los verdaderos protagonistas, los grupos políticos con representación parlamentaria —en la expresión del art. 99 $\mathrm{CE}$ - , y donde la figura del Presidente del Congreso se revela como la persona clave en este momento, asegurando y atestiguando la corrección de la intervención del Rey. Es una obviedad señalar que el candidato no es del Rey, sino que 
sólo se canaliza a través del mismo, y éste ni se involucra, ni debe involucrarse. Se constatarán en este trámite las mayorías existentes y/o los acuerdos adoptados por las diferentes fuerzas políticas o en su caso la posibilidad de llegar a los mismos. Técnicamente nada impide que se amplíe el radio de consultas más allá de lo estrictamente previsto por el art. $99 \mathrm{CE}$, aunque realmente parece difícilmente imaginable una hipótesis en la que ello pudiera resultar de alguna utilidad. El Rey no puede salirse del guion que marque con claridad la representación popular y que acota la dinámica político partidista; cualquier otra actuación puede terminar por desgastar (todavía más) la institución. Nada debe comprometer su neutralidad institucional; ni siquiera en los casos de «hung Parliament» parece oportuno cambiar dicho rol (sobre esta cuestión, vid. Bogdanor, The Monarchy and the Constitution, 1997). Existen más riesgos que ventajas. No creemos sinceramente que en estos casos la supuesta auctoritas del monarca pudiera servir de válvula de escape, cuando es en los partidos donde reposa claramente toda la responsabilidad del proceso. Como apunta Aragón Reyes las virtudes de la Monarquía parlamentaria sólo operan a través de la prudencia política, tanto del Rey como de las fuerzas políticas («La Monarquía parlamentaria», La Constitución española de 1978, García de Enterría - Predieri, Coords. 1981).

No es ocioso recordar, para terminar este apartado, que inicialmente el Borrador de la Ponencia del texto constitucional excluía al Rey de esta primera parte del proceso de investidura ordinario relegándole a la fase última, el nombramiento del candidato elegido por el Congreso; por cierto, sin debate de ningún tipo en un primer momento y con la obligación de presentarse nuevamente ante la Cámara con su equipo de gobierno. Quizá no hubiera resultado mala opción haber dejado aquella inicial redacción.

\section{JOSEFA RIDAURA MARTÍNEZ}

En los sistemas políticos contemporáneos el fortalecimiento del principio democrático ha tendido a reducir el protagonismo que históricamente han tenido los Monarcas en el proceso de elección de los Jefes del Ejecutivo. Precisamente por ello, el texto constitucional español de 1978, al configurar la Monarquía como órgano de arbitraje y moderación, se ha apartado de los precedentes de designación del Jefe del Ejecutivo por el Jefe del Estado, confiriéndole en este proceso un papel preminente al Congreso de los Diputados. En este ámbito, el protagonismo de la Cámara es consustancial al parlamentarismo por el que optó el constituyente, ya que en el ADN del régimen parlamentario está que el Ejecutivo cuente con la confianza del Legislativo, tanto para su existencia como para su subsistencia.

El texto constitucional, en el artículo 99 regula, pues, una intervención regia limitada. Y es que en este marco de clara preeminencia de la Cámara de 
representación de la soberanía popular, el relieve del papel del Rey en la consulta realizada a los grupos para la propuesta de un candidato a la presidencia del Gobierno está estrechamente condicionado por las mayorías obtenidas por cada grupo en los comicios. En efecto, en un Congreso configurado por grupos parlamentarios con mayorías holgadas, la función del Rey es de trámite; especialmente, si algún grupo cuenta con mayoría absoluta, pues el candidato que deberá proponer el Rey será, claramente, el cabeza de lista, el líder de ese grupo parlamentario.

Sin embargo, cuando no se ha obtenido la mayoría absoluta por ningún grupo, el Rey puede alcanzar mayor notoriedad como árbitro del proceso; no obstante, tampoco en este caso puede desconocer la conformación numérica de cada grupo, ya que debería estar orientada a asegurar no sólo la investidura, sino una posterior acción de gobierno efectiva $-\mathrm{y}$, a poder ser, estable-. Es casi imposible, pues, que la propuesta regia dirija su mirada hacia candidatos no propuestos por algún grupo parlamentario. Sobre todo, porque ha de tenerse en cuenta que los candidatos a la presidencia, son, casi siempre, los líderes de sus partidos, en el marco de un Parlamento de Grupos, como sujeto principal de la actuación parlamentaria, con una fuerte disciplina que emana de las secretarías generales.

Ciertamente, constituye una prerrogativa regia proponer candidato a la Presidencia del Gobierno; en consecuencia, el Rey, eventualmente, podría proponer a un técnico, ajeno a los partidos, para salvar una situación prolongada de no-acuerdo. Pero es poco probable que esto suceda. La operación regia está encaminada a que un candidato logre la confianza de la Cámara, de ahí que, tras escuchar las propuestas y posiciones de los partidos, es la confianza en su buen criterio la que le conducirá a proponer candidatos que tengan posibilidades reales de alcanzar los apoyos necesarios.

La moderación y neutralidad regias (Constant) han de permitirle cierto margen de discreción para no dejarse arrastrar por presiones de propuestas abocadas al fracaso; pues, además, ésta ha de hacerse, no sólo pensando en alcanzar con éxito la investidura, sino en su continuidad y estabilidad para la formación y desarrollo de la acción de gobierno; de lo contrario podríamos encontrarnos ante un nuevo bloqueo institucional.

Sin mermar el claro protagonismo que ha de tener la Cámara y, señaladamente, su Presidente, no creo que su refrendo deba dejar sin margen de actuación al Rey. Precisamente, porque su exigida neutralidad no puede predicarse en los mismos términos de la Presidencia de la Cámara, ejercida por un integrante de un grupo político con representación parlamentaria.

Por último, no me parece determinante regular la figura del informador, ya que podemos preguntarnos si, realmente, dicha previsión normativa es necesaria. Pensemos que no está cerrada la posibilidad de que el Rey cite en la ronda de consultas a personas que no forman parte de ningún grupo político con representación parlamentaria, incluso podrían ser personas de reconocido prestigio profesional, o personas de su confianza. El 99.1 CE se refiere a la «previa consulta 
con los representantes designados por los grupos políticos con representación parlamentaria...». Ello determina la necesidad de entrevistarse con todos ellos, pero no de manera excluyente; de forma que no se aprecia obstáculo alguno para se reúna con cuantas otras personas estime conveniente, siempre y cuando su actuación esté dirigida al mejor cumplimiento de su función: proponer un candidato a la presidencia que pueda contar con apoyos suficientes.

\section{MARÍA ESTHER SEIJAS VILLADANGOS}

La constitucionalización de una monarquía parlamentaria tiene, al hilo de lo cuestionado, dos consecuencias como mínimo: primero, ninguno de sus protagonistas puede ser desconectado de los demás, no cabría un tratamiento de los actores como compartimentos estancos, y, segundo, los argumentos que justificaron el maridaje entre «monarquía y parlamento» claman por una continua fundamentación, por una reiterada reivindicación de lo razonable de su inclusión constitucional (E. García, 2014). Esto es, no solo podemos centrarnos en el Rey y cualquier coyuntura parece propicia para el cuestionamiento de la monarquía.

El Rey es el jefe del Estado, «símbolo de su unidad y permanencia» y, lejos de ser un poder más, ostenta un status supra-partes implementado a partir de tres derechos identificados meridianamente por Bagehot (1867): el derecho de ser consultado, el derecho de animar y el derecho de advertir. A partir de esa base, el Rey arbitra y modera el funcionamiento de las instituciones desde un parámetro de estricta neutralidad que se fundamenta en el distanciamiento hacia las otras partes, reforzado por su no elegibilidad, y que potencia su legitimidad como símbolo de unidad, su credibilidad, razonabilidad (Locke, 1695) y su utilidad a la democracia (Constant y Bagehot). Dicha neutralidad no es, para nada, sinónimo de inutilidad inactiva. El ámbito funcional desde el que se desarrolla su capacidad integradora implica funciones jurídicas (arts. 62 y 63 CE) y elementos meta jurídicos que abogan por implementar los principios y valores constitucionales desde la prudencia y desde ese cuerpo invisible (Kantorowicz, 1957) sobre el que pivota su auctoritas, contribuyendo a que la ficción Corona ayude a preservar lo que la Constitución ha garantizado. En ese espacio, un Rey de una monarquía parlamentaria tiene un margen para habilitar y revitalizar cauces procesales de actuación para "promover el diálogo, la concertación y el compromiso» (Comunicado de la Casa de su Majestad el Rey de 5 de septiembre de 2016), más allá de una mera constatación de la posibilidad de proponer a un candidato a la presidencia con suficientes apoyos, sin que ello derive en una significación sustantiva hacia ningún candidato, ni en formular propuestas cuando nadie se postula y mucho menos en presentar sucesivas propuestas aleatorias como si se tratara de un juego de azar. Estaríamos ante una actuación no reglada, pero por otro lado obligada, para quién desde una prerrogativa específica de irresponsabilidad, tiene el deber de proteger el orden constitucional y sus protagonistas. Una 
irresponsabilidad, concebida como excepción, que no puede definirse como una antinomia —el monarca sería incontrolable—, ni en términos absolutos — la concepción de un órgano anulado política y jurídicamente por el sujeto refrendante- (B. Oliver, 2004), pero sí de forma ontológica merced a la conexión entre los preceptos 9.3, 56.3 y 64 CE. La irresponsabilidad del Rey niega su discrecionalidad y las sanciones aparejadas a la misma, pero no le exime del cumplimiento de los deberes jurídico-constitucionales de un Jefe de Estado.

En el desempeño de esa obligación constitucional el Rey puede actuar directamente o de forma mediata. Al supuesto belga nos hemos referido en otra ocasión (Los Gobiernos de los Estados en la Unión Europea, 2011) y respecto al caso sugerido de Holanda entendemos oportuno un repaso de su experiencia. La Constitución holandesa de 1815 estipula en su art. 42 que el Gobierno estará integrado por el Rey y los Ministros. Esa implicación del monarca en el poder ejecutivo se reduce de facto a nombrar y destituir al Primer Ministro y a los demás Ministros (art. 43) para lo que se requiere el refrendo (art. 49). A partir de ahí, el proceso de formación de un nuevo Gobierno discurre al margen de cauces legales, articulándose en torno a tres fases: explorativa, constructiva y formativa que pivotan en torno a la Cámara Baja, curiosamente designada como Segunda Cámara (Tweede Kamer der Staten General). No obstante, conviene recuperar tres presupuestos del sistema político holandés (R. Andeweg y A. Irwin Galen, 2014), que si hasta el momento presente nos parecían sumamente extraños, podrían ser de ahora en adelante muy familiares a la realidad española.

Primero, la «pilarización» (pillarization), neologismo con el que se alude a los distintos pilares o minorías sobre los que se asienta la sociedad holandesa, no solo en el ámbito social o religioso, sino particularmente en el político. No hay partidos mayoritarios en Holanda y, probablemente, nunca los habrá.

Segundo, la «democracia consocional», (A. Lijphart 1969) que apela a la viabilidad de la democracia en aquellos Estados con gran fragmentación política y con una tendencia desintegradora. Cuatro características la definen: Gobiernos de coalición de composición proporcional respecto a los resultados electorales; veto mutuo entre sus miembros; importante grado de autonomía de cada sector integrante y, ante todo, la gran voluntad y la cooperación de las élites para sustentarlo.

Tercero, el modelo «Polder» o «Polderen» (Brouwer, 1990), con el que se alude a una forma pragmática de tomar decisiones, basada en el consenso y que involucra a todos los partidos y grupos sociales, presentes o ausentes en el Gobierno.

La designación de un «informateur» por la Cámara Baja, y con anterioridad a 2012 en que se introduce un nuevo artículo 139 a) en su Reglamento, por el mismo Rey sobre la base de las prospectivas de coalición que tras las elecciones un «explorador» parlamentario ha identificado es el punto de salida. Esta tarea casi siempre ha recaído en hombres, salvo en 2017 con Edith Schippers, que han destacado por un reconocimiento de su valía política más allá de su propio entorno y que en ese momento estén relativamente al margen de la vida política activa. $\mathrm{Su}$ tarea es explorar las potenciales coaliciones que puedan configurarse, 
identificando las diferencias sustanciales que las vetarán y a los partidos políticos imprescindibles en las mismas. El protagonismo del Rey se situaba, antes de 2012, al comienzo y al final del trabajo referido. Inicialmente, se percibía como un guía neutral que transmitía instrucciones de modo muy cauteloso, buscando siempre preservar su deber constitucional de protección de las minorías. Los consejeros permanentes del monarca (Presidentes de las dos Cámaras y Vicepresidente del Consejo de Estado) aportan su visión de proceso, que no se hacía pública pero se entregaba al futuro «informateur». El Rey recibía a los líderes de los partidos que habían obtenido un escaño en la Cámara de Representantes en orden correlativo al número de escaños, formulando a todos las mismas cuestiones: 1. «¿Cuál es su interpretación de los resultados de la elección? 2. ¿Cuáles son las opciones para una coalición? 3. ¿Cuál de ellas debería ser explorada en primer lugar? 4. ¿Quién debería actuar como «informateur» y con qué instrucciones? A partir de ese «ritual de objetividad» (H-Tjeenk Willink, 2016) se identificaría al «informateur» y se le trasladaría la información esencial para el desarrollo de su trabajo que se centrará en las siguientes tareas: proteger al Rey de un fracaso político, asumiendo toda la responsabilidad del proceso; enfriar el debate tras el acaloramiento electoral; acercar a los partidos a conclusiones difíciles de alcanzar desde sus planteamientos singulares y salvar del fracaso al futuro «formateur», generalmente el futuro primer ministro que no aparece en escena hasta el momento de seleccionar a los potenciales ministros. Los informes remitidos al Rey por los informadores y formadores son ahora remitidos a la Cámara Baja, donde se debaten, publican e incluso se requiere la comparecencia del informador. La parlamentarización de ese proceso y su intrínseca politización, evidenciada en la designación de un miembro destacado del partido vencedor como mediador ha tensionado el papel de Rey en ese proceso y su cometido constitucional y convencional de salvaguarda de las minorías, es decir en un trayecto inverso a lo vivido en España parece añorarse el protagonismo regio en el proceso. Un último comentario nos lleva a los plazos y a la realidad. La reforma del Reglamento de la Cámara Baja (art. 139 a. 2 y 3) señala el plazo efímero y utópico de una semana, tras la conclusión de las tareas del informador, para nombrar a un formador y para que éste culmine su trabajo configurando un Gobierno. La realidad es que las dificultades para formar Gobierno, alcanzando los consensos precisos se agravan en Holanda donde recientemente la informadora inicialmente designada ha concluido su trabajo, asumiendo su fracaso y procediéndose a nombrar a alguien experimentado como Herman Tjeenk Willink que ya desempeñó esa tarea en 1994, 1999 y 2010. Así, Holanda y el líder del partido con más escaños, Rutte (VVD) siguen esperando.

Desde las experiencias de Bélgica y Holanda, la ventaja de introducir esos intermediarios en el proceso de formación de un Gobierno no se ha probado como garantía de un recorte de los plazos, tampoco de una desvinculación total del monarca - remedio teórico para paliar una degradación de la monarquía, cuya presencia por otro lado parece añorarse- De ese modo, su contribución se 
focaliza en visibilizar el proceso, identificando las responsabilidades de los actores con potenciales consecuencias electorales ulteriores siempre difíciles de vaticinar. No obstante, sin una cultura política y constitucional previa, los visos de éxito de la importación de estas prácticas quedarían muy minorados.

$3^{a}$. ¿Qué importancia concede usted al control político por las Cámaras del Gobierno, cuando está en funciones? ¿El que un Gobierno tras la celebración de elecciones generales esté en funciones, supone a su juicio una supresión o aminoración de las competencias especificas de control que las Cámaras y sus comisiones tienen respecto del Gobierno y cada uno de sus miembros?

\section{JAVIER GARCIA FERNANDEZ}

Como las dos partes de la pregunta redundan en la misma cuestión, voy a tratarlas conjuntamente, en el mismo sentido que ya lo hice hace tiempo en un medio de comunicación hoy desaparecido ( El Gobierno en funciones ante el control del Congreso», Abora, 15 de abril de 2016). En primer lugar, hay que decir que la Constitución ha previsto la situación del Gobierno cesante pero esa situación no resta ninguna de las facultades que corresponden a las Cortes Generales, entre ellas, controlar la acción del Gobierno. En segundo lugar, en ningún norma positiva (ni tampoco en la doctrina) se ha dicho que el control parlamentario del Gobierno trae causa de que éste tiene establecida una relación fiduciaria con el Parlamento pues si así fuera el Senado no podría ejercitar funciones de control, que obviamente las ejercita (lo mismo en Estados presidencialistas como Estados Unidos y Méjico, donde también existe el control parlamentario).

Con este doble punto de partida entiendo que las Cortes Generales, en sus dos Cámaras, han de controlar al Gobierno cesante. Y ello, por otras dos razones adicionales. En primer lugar, el Gobierno en funciones no es un Gobierno paralizado sino que, conforme al artículo 101.2 de la Constitución y al artículo 21.2 y 3 de la Ley 50/1997, de 27 de noviembre, del Gobierno, tiene un radio de acción limitado pero real. Quiere ello decir que en el ejercicio del «despacho ordinario de los asuntos públicos» (artículo 21.3 de la Ley del Gobierno), el Gobierno puede incurrir en cualquier extralimitación de carácter jurídico o de naturaleza política, que el Parlamento habrá de controlar en aplicación del artículo 66.2 de la Constitución. En segundo lugar porque lo contrario nos llevaría a la paradoja (no deseada por la Constitución) de que el único caso de un Gobierno que carece de confianza parlamentaria tuviera una ilimitada libertad de acción, por ausencia de control. No debemos olvidar, en fin, que el Gobierno en funciones no puede ser sometido a la moción de censura por lo que si no se somete a los instrumentos de control estaríamos ante un Gobierno incontrolable. 


\section{ÁNGEL J. GÓMEZ MONTORO}

En un régimen parlamentario, el control del Gobierno debe existir siempre, también cuando está en funciones. Otra cosa es que, lógicamente, deberá adaptarse a la propia realidad de un Ejecutivo que no ha recibido la confianza de las nuevas Cortes y que tiene sus funciones considerablemente limitadas.

Desde luego, y puesto que no existe una relación fiduciaria entre el nuevo Parlamento y el Gobierno en funciones, no cabe ninguna de la formas de control que llevan consigo la retirada de la confianza (moción de censura) o su reforzamiento (cuestión de confianza). Como tampoco procede, a mi entender, promover reprobaciones de miembros singulares del Gobierno. Pero no cabe confundir el control parlamentario con la exigencia de responsabilidad. En un régimen democrático no puede haber poder sin control, ni un régimen parlamentario en el que la actuación del Ejecutivo quede libre de la fiscalización del Parlamento. Por eso, considero que el Gobierno sigue estando sometido al control por parte del Parlamento y, más en concreto, a los instrumentos ordinarios: comparecencias, preguntas, interpelaciones...

\section{JOSÉ ANTONIO MONTILLA MARTOS}

Nuestra Constitución se refiere a la figura del Gobierno en funciones cuando dice el 101.2 que «el Gobierno cesante continuará en funciones hasta la toma de posesión del nuevo Gobierno». Se presupone, por tanto, la limitación de su capacidad de actuación, pero no dice nada sobre sus competencias, a diferencia de lo que hacen otras constituciones como la alemana (art. 69.3) o la portuguesa (art. 189.5) que limitan expresamente su actuación a los asuntos de trámite. Como sabemos, es la Ley 50/1997, del Gobierno la que se ocupa de esta cuestión en su artículo 21. En líneas generales, el planteamiento que hace esta Ley me parece adecuado. El Gobierno en funciones desarrolla su actuación en dos direcciones: por un lado, para facilitar el proceso de formación y el traspaso de poderes al nuevo gobierno; por otro, debe ceñirse en su gestión al despacho ordinario de los asuntos, absteniéndose de adoptar otras medidas salvo supuestos de urgencia debidamente acreditada o por razones de interés general cuya acreditación expresa así lo justifique. A partir, de ahí establece una serie de limitaciones concretas a la actuación del Gobierno en funciones.

Sin embargo, la Ley del Gobierno nos habla de atribuciones y de límites pero no de control de la actuación del Gobierno en funciones. Esa imprevisión de las formas de control es el principal problema de esta regulación como ha demostrado la reciente experiencia de un largo periodo de Gobierno en funciones (314 días) durante el cual este se ha mostrado insumiso al control parlamentario, utilizando la expresión de Fernando Reviriego. 
El control del gobierno en funciones puede ser judicial y político. Sobre el primero, poco que decir. La extralimitación del gobierno en funciones puede ser sometida a control judicial como control de legalidad. En este sentido, el Tribunal Supremo ha establecido una doctrina según la cual las decisiones del gobierno en funciones no pueden adoptar nuevas orientaciones políticas ni «condicionar, comprometer o impedir» la actuación del Gobierno que lo sustituya. En ese contexto, habrá que analizar en cada caso si la actuación del Gobierno en funciones ha sido adecuada en cuanto se encuadra en el despacho ordinario de los asuntos o puede ser justificada por razones de urgencia o interés general.

Los problemas se plantean en relación al control parlamentario. Y ello porque, como es sabido, el Gobierno que ha ejercido en funciones la dirección política de España durante prácticamente todo 2016 ha argumentado en diversos escritos dirigidos al Congreso de los diputados y en informes publicados por la prensa con origen en la Secretaría de Estado de Relaciones con las Cortes que no debía atender los requerimientos de control de las Cortes Generales, en concreto del Congreso, en la medida en que no existía una relación de confianza entre un Gobierno en funciones y el Congreso recientemente constituido. El único control posible sobre su actuación era un control de legalidad a partir de las posibles extralimitaciones en que pudieran incurrir en el ejercicio de sus atribuciones y ese control corresponde al Poder Judicial.

Sin embargo, paradójicamente, esa doctrina ha sido matizada en algunos supuestos en los que si voluntariamente, y en algunos casos por propia iniciativa, se ha sometido a control. La paradoja es evidente: el controlado decide en qué casos debe someterse a control, lo que supone, obviamente, subvertir completamente la función de control. Esta situación ha dado lugar a un conflicto de atribuciones ante el Tribunal Constitucional, cuya interposición fue aprobada por todos los grupos parlamentarios salvo el Popular. Al resolver este conflicto el Tribunal debería establecer algunas pautas sobre esta relación, más allá de confirmar lo obvio: que el Gobierno en funciones debe someterse a control parlamentario.

En este sentido, creo que se pueden apuntar algunos elementos para acercarse a esta cuestión. Empecemos por lo más importante: el gobierno en funciones debe someterse al control parlamentario. Lo contrario significaría aceptar que un órgano constitucional puede actuar sin contrapeso, en definitiva que durante el periodo de gobierno en funciones no existe división de poderes. Como se dice en el conflicto de atribuciones presentado por el Congreso, sería una grave anomalía constitucional la existencia de un gobierno en funciones que carece de responsabilidad política, sin que el órgano de representación de la voluntad popular pudiera constatar que cumple correctamente, sin excederse y sin hacer dejación, las funciones que le corresponden.

En segundo lugar, es evidente que el control a ejercer es el denominado control-fiscalización que se ejerce a través de solicitud de información, preguntas, interpelaciones, mociones, resoluciones o proposiciones no de ley. No resultan aplicables los instrumentos de control-exigencia de responsabilidad política, esto 
es, la cuestión de confianza y la moción de censura pues se vinculan directamente a un gobierno en plena actividad. De la misma forma que el Presidente del Gobierno en funciones no puede ejercer el derecho de disolución tampoco se le puede exigir responsabilidad política.

A partir de ahí, la cuestión a dilucidar es el alcance de este control. En principio, el control que ejerce el Congreso sobre el Gobierno es ilimitado en el sentido de que pueden utilizarse todos los instrumentos de control fiscalización previstos en el ordenamiento. En cualquier caso, es cierto que el Gobierno en funciones sólo podrá responder del ejercicio, por acción u omisión, de las competencias que tiene reconocidas. Si es competente para adoptar una decisión, dicha decisión debe ser controlada. Y, sin duda, son muchas las decisiones que adopta el Gobierno en funciones tanto de naturaleza normativa como administrativa. Durante el gobierno en funciones no se han aprobado leyes, más allá de un decreto ley para el mantenimiento de un programa de protección por desempleo y dos leyes orgánicas vinculadas a la propia situación de gobierno en funciones, pero si se han aprobado numerosos Reales Decretos sobre diversas materias, incluso de desarrollo de leyes con un importante contenido normativo.

En este sentido, no puede ser controlada su actuación futura o el desarrollo del programa de gobierno pues son decisiones vinculadas a la dirección política del Gobierno que escapan a las competencias de un gobierno en funciones y, por tanto, a su control. Más problemas plantea el control de situaciones del pasado, esto es, la utilización de estos instrumentos para el control del gobierno que cesó. En este caso, para ser objeto de control deberá establecerse una vinculación con las situaciones del presente en relación a las cuales el gobierno en funciones ejerce sus competencias.

Tampoco me parece que haya impedimento para que se planteen iniciativas legislativas por parte de los grupos parlamentarios, aun cuando el Gobierno no pueda presentar proyectos de ley ni ejercer la función presupuestaria. Las Cortes Generales no están en funciones y, por tanto, pueden desarrollar su actividad legislativa. Recuérdese que el Gobierno puede también desarrollar una limitada actividad legislativa a través de la aprobación de decretos leyes, si se cumple el presupuesto habilitante, y, lógicamente, puede oponerse a la tramitación de estas iniciativas legislativas de Congreso y Senado en aplicación del art. 134.6 CE. Sin embargo, con esa importante limitación no encuentro razón para impedir la iniciativa legislativa parlamentaria.

En el mismo sentido de relación entre ambos órganos, la Ley del Gobierno dice que el Gobierno en funciones deberá acreditar las razones de urgencia o de interés general que justifican su actuación, más allá del despacho ordinario de los asuntos. Está claro que es el Gobierno en funciones quien debe acreditar estas razones pero dicha acreditación debe hacerse ante alguien, más allá de su posible control judicial. Coincido con María Rosa Ripollés en que esa acreditación sólo puede ser ante el Congreso de los Diputados, si aplicamos analógicamente lo previsto en el artículo $108 \mathrm{CE}$ según el cual el Gobierno «responde solidariamente 
de su gestión política ante el Congreso de los Diputados». Esto resultaría aplicable a los Reales Decretos y Ordenes Ministeriales que ha ido aprobando el Gobierno en funciones sobre asuntos de gran relevancia y en algunos casos no exentos de polémica. En virtud del criterio anterior, deberían haber sido conocidos por el Congreso. En cualquier caso, entiendo que el art. 21 de la Ley del Gobierno debería hacer una referencia expresa a esta cuestión del conocimiento por el Congreso de las decisiones adoptadas por el Gobierno por razones de urgencia o interés general.

En conclusión, el planteamiento correcto es, a mi juicio, justo el inverso al sostenido por el gobierno durante este largo periodo de gobierno en funciones. Según su interpretación, al no existir relación de confianza de ese gobierno cesante con las nuevas Cortes Generales sólo excepcionalmente se podrán aceptar iniciativas de control mientras que la mayoría de estas iniciativas se entienden aplazadas hasta la constitución del Gobierno. Frente a ello, entendemos que las Cortes Generales, una vez constituidas, podrán utilizar todos los instrumentos de control fiscalización que la Constitución les reconoce en relación al gobierno en funciones. A partir de ello habrán de acotarse los supuestos en los que ese control no resulta posible porque no se vincula a las competencias del gobierno en funciones, al exceder su ámbito de actuación, referirse a situaciones estrictamente vinculadas al gobierno que ya cesó o a situaciones futuras cuya decisión corresponde adoptar al gobierno una vez constituido. En definitiva, lo excepcional no es el control sino el impedimento de ese control. De la misma forma se podrá ejercer la iniciativa legislativa por los grupos parlamentarios, aunque el Gobierno mantiene la habilitación constitucional para oponerse a su tramitación derivada del art. 134.6 CE, y, por último, cuando el Gobierno en funciones no se limita al despacho ordinario de los asuntos sino que adopta decisiones por razones de urgencia o interés general deberían acreditarse estas razones ante el Congreso para lo que resultaría adecuada una modificación en ese sentido de la Ley del Gobierno.

\section{MIGUEL REVENGA SANCHEZ}

En mi opinión, el control político del Gobierno en funciones es un ingrediente tan necesario de nuestro sistema constitucional como la propia existencia de la «prorrogatio» del Gobierno cesante. El control inter-orgánico pertenece a la esencia misma de la democracia constitucional y me resulta literalmente incomprensible que la imposibilidad de extraer las consecuencias constitucionalmente asignadas a lo que a veces se llama el «control-sanción», pueda esgrimirse como argumento para eludir el sometimiento genérico a una forma de control que resulta inherente, como digo, a la forma política — por usar la expresión constitucional - por la que hemos optado. Y mucho menos cabe utilizar como argumento el hecho de que, al haberse producido una renovación de las Cámaras, ha quebrado fatalmente la relación de confianza instituida en su día entre ellas 
- más bien la que actuó para investir como presidente al que ahora lo está en prórroga de funciones- y el presidente cesante. Esto supone, a mi juicio, un retorcimiento hasta el absurdo de la lógica subyacente al tipo de control político realizado desde el Parlamento. Si estamos de acuerdo en que el vínculo de responsabilidad política es un vínculo de carácter institucional, y no uno instituido «ad personam» entre el presidente y todos y cada uno de los que votaron favorablemente a la investidura, ello es por sí sólo argumento bastante para defender que el Gobierno cesante debe estar tan sujeto al control genérico de las dos Cámaras como lo está el Gobierno en plenitud de atribuciones por imperativo del artículo 67.2 de la Constitución. A mayor abundamiento: con una fórmula como la que tenemos en la Ley de Gobierno dirigida a enmarcar las atribuciones del Gobierno cesante tanto en sentido positivo (artículo 21.3 de la Ley 50/1997) como en sentido negativo (artículo 21.4 y 21.5 de la misma Ley), el control político del Parlamento, llámese control/vigilancia, control/información o control en corto, es la única manera en la que, en combinación con el control de naturaleza jurisdiccional, puede darse cabal cumplimiento al artículo 26 de la propia Ley 50/1997, cuyo Apartado 2 deja en esto poco resquicio para interpretaciones extravagantes o «imaginativas»: «Todos los actos y omisiones del Gobierno están sometidos al control político de las Cortes Generales». En el lenguaje jurídico «todos» significa lo mismo que en el lenguaje ordinario; y no habiendo previsión expresa que excepcione, singularice o matice dicha facultad parlamentaria para el trance constitucional en el que justamente el Gobierno (en funciones) sí tiene unas limitaciones bien claras y expresas, mal puede defenderse una suerte de inmunidad al control de la que, por lo demás, no se alcanza a entender qué rédito político podría extraerse. Dicho lo cual, no me resisto a añadir que es una lástima que la agenda del Tribunal Constitucional, tan (justificadamente) adaptable a la imperiosa necesidad de decidir con urgencia, no haya reflejado en este caso sensibilidad alguna para establecer sobre el particular, y con prontitud, una interpretación autorizada.

\section{FERNANDO REVIRIEGO PICÓN}

Las Cortes Generales controlan la acción del Gobierno y lo hacen en todo momento. Esta actividad de control, como ha señalado el Tribunal Constitucional en diferentes ocasiones, integra la esencia de la actividad parlamentaria.

El Gobierno cesante que permanece en funciones hasta la toma de posesión del nuevo Gobierno está sujeto a dicho control, pudiendo cobrar incluso mayor valor o relevancia en estos momentos. Si bien el ejercicio de dicho control durante esos interregnos ha acostumbrado a ser inexistente por causa de diferentes factores, entre ellos la habitual brevedad de estos períodos (hasta esta última ocasión la media era de apenas cuarenta días) o la certeza de la próxima investidura, ello no impide poner de manifiesto que la legitimidad menor, o la legitimidad 
reorientada si se prefiere, que tiene un Gobierno en este estado, no puede permitir una mayor libertad de acción y una ausencia de control. Su condición de pieza esencial del edificio constitucional del parlamentarismo, en palabras de Montero Gibert y García Morillo (El control parlamentario, 1984), pervive lógicamente durante estos períodos.

No compartimos por ello en modo alguno el argumento utilizado por el Gobierno que permaneció más de diez meses en funciones tras las elecciones de diciembre de 2015 para escapar a dicho control: «La Cámara no puede someter al Gobierno en funciones a iniciativas de control en la medida en que no existe una relación de confianza entre éste y el Congreso de los Diputados».

Sostener esa ausencia de control sobre el Gobierno es sin duda una grave anomalía democrática, que incide de forma directa en el sistema de equilibrio y colaboración de poderes. El Gobierno en funciones es Gobierno.

Quevedo, en sus Sueños y Discursos, nos habló del personaje Pero Grullo, famoso por sus profecías, como esa que decía «Volarase con las plumas, andarase con los pies, serán seis dos veces tres». De ahí nos queda en el diccionario que perogrullada es una verdad o certeza que, por notoriamente sabida, es necedad o simpleza el decirla. Pues bien, lo cierto es que el que está en funciones es el Gobierno no el Parlamento.

No resulta en modo alguno posible hablar de la inexistencia de vínculo fiduciario como elemento articulador de la falta de control, pues (nuevamente seis son dos veces tres), ello nos llevaría a plantearnos, como siguiente providencia, las implicaciones de este argumento (en cualquier situación, en funciones o no) para una Cámara como el Senado que no participa en ningún caso en la investidura y que no tiene, por tanto, ningún vínculo de este tipo con el Gobierno.

El control de la acción del Gobierno corresponde a las Cortes Generales, al igual que corresponde también a las Cámaras, por ejemplo, y de forma más específica, solicitar información y ayuda del Gobierno, reclamar la presencia de los miembros de éste o poder plantear preguntas o interpelaciones. Ninguna de estas prerrogativas queda limitada durante la permanencia en funciones. Una cuestión diferente es que pueda ser preciso hacer algunas modulaciones en función del ámbito competencial de ese Gobierno, pues como ha apuntado recientemente Landelino Lavilla, el objeto del medio de control o de información no puede ni debe ser ajeno al campo de acción del Gobierno: «la medida del objeto del control está condicionada por los límites de las competencias de un Gobierno en funciones» («El control parlamentario del Gobierno en funciones», RACMP, 2017). Y, por ello, cabe inadmitir iniciativas que no estén en ese ámbito o que se refieran a políticas de futuro, y así se ha hecho en esta larga permanencia en funciones, ya que a la par que se solicitaban comparecencias o presentaban preguntas, la propia Mesa del Congreso rechazaba preguntas por exceder ese ámbito competencial; por ejemplo, preguntas sobre el futuro sistema de financiación autonómico que se inadmitieron al considerarse que eran responsabilidad del futuro gobierno. 
También se procedió a solicitar la reformulación de algunas iniciativas para adecuarlas a la competencia propia de un Gobierno en funciones.

La propia Ley del Gobierno, que reguló detalladamente la permanencia en funciones del Gobierno, se encarga de destacar que «todos» los actos y omisiones del Gobierno están sometidos al control político de las Cortes Generales; ello sin distinción alguna de la concreta circunstancia en que pudiera encontrarse el Gobierno. Mas, aunque no dijera nada, las previsiones constitucionales son claras.

Como señala López Guerra («Gobierno en funciones», Temas básicos de Derecho constitucional, 1995), la propia prorrogatio encuentra justificación «no sólo por la necesidad del mantenimiento de las tareas de Gobierno, sino también para que exista una posibilidad de control (parlamentario y judicial) de las acciones gubernamentales, con responsables definidos». De esta forma, persiste indiscutiblemente, en palabras de Guillén López, la actividad fiscalizadora tanto porque «no hay ninguna previsión expresa o tácita, constitucional o reglamentaria (como sí se encuentra en algunos subsistemas normativos autonómicos) que lo limite» como «porque sobre las bases del sistema parlamentario es muy difícil, por no decir imposible, admitir que (..) el Gobierno en funciones no esté sometido a control político alguno» (El cese del Gobierno y el Gobierno en funciones en el ordenamiento constitucional español, 2002). Es éste (seguimos insistiendo en ello) quien se encuentra en funciones, no el Parlamento.

Pueden, por tanto, plantearse preguntas, solicitarse comparecencias, etc., ya que sostener una ausencia de control es una notable perversión democrática.

Curiosamente, el Gobierno en funciones se apoyó para sostener esta postura en el Informe emitido por la Secretaría General del Congreso de los Diputados al poco de constituirse la Cámara tras las elecciones de diciembre de 2015, pero lo cierto es que dicho Informe (aunque con una redacción no muy clara en ocasiones) sostenía precisamente que dicho control permanecía, pero circunscrito a ese ámbito competencial restringido y acotado por la Ley.

Este posicionamiento de partida del Gobierno le llevó a sostener un criterio general de no sometimiento al control parlamentario, concretado en la negativa a responder preguntas parlamentarias, acudir a comparecencias solicitadas en Pleno o en Comisión.

Ahora bien, esta posición apriorística se mantenía a la par que, por otro lado, se solicitaban por el propio Gobierno comparecencias con el objeto de informar sobre reuniones del Consejo Europeo en el que se abordaron cuestiones como el Brexit o la crisis de los refugiados. Cuestiones aparentemente análogas en su relevancia recibían respuestas distintas. De hecho, la negativa en el caso de la comparecencia solicitada para informar sobre una reunión de los Ministros de Defensa de la OTAN se encuentra precisamente en el germen de la presentación del conflicto. Fue la primera vez (primera de muchas) en que este Gobierno en funciones se negó a someterse al control parlamentario en sentido lato. Tras esta negativa a 
comparecer en la Comisión de Defensa llegarían otras comparecencias, solicitadas y negadas, ante las Comisiones de Fomento, Industria, Medio ambiente, Interior, etc.

De alguna manera nos situábamos ante un escenario con los papeles cambiados, en los que el controlado indica al controlador cuándo cabe dicho control; y donde el controlado es también quien decide cómo y dónde, si en Comisión o Pleno.

Esta idea fue muy bien reflejada en el escrito en el que se planteó el recurso ante el Tribunal Constitucional como «control a la carta»; así, «según el criterio del Gobierno en funciones, es a este órgano a quien corresponde decidir cuándo procede comparecer ante las Cámaras y sus comisiones y cuándo no, lo que resulta inadmisible, toda vez que implicaría una completa subversión del sentido de la función de control, dejando en manos del órgano o sujeto controlado la decisión sobre si procede el control en cada caso. Esta auto atribución que hace el Gobierno, aparte de que carece de cualquier apoyo constitucional, supone ignorar las atribuciones de la Cámara y suplantar la competencia de la Mesa de calificación de las iniciativas».

Esta posición no se contradice con el hecho apuntado supra de valorar la especial situación del Gobierno en estos períodos (vid. García Roca, « ¿Puede rechazar el control parlamentario un Gobierno en funciones», y Elvira Perales, «Control parlamentario», los dos trabajos en Lecciones constitucionales.., 2017), y así, por ejemplo, puede ser difícilmente comprensible la formulación de interpelaciones sobre política general cuando el Gobierno en funciones no se encuentra en condiciones de acometerla (Arce Janariz, «Insuficiencias del control parlamentario en las Comunidades Autónomas», Informe Comunidades Autónomas, 1996). Una iniciativa de este tipo podría ser en su caso no admitida a trámite por la Mesa, aunque pudiera resultar compleja esta actuación ya que la valoración de la misma queda sujeta en los reglamentos a la adecuación de la misma al significado de una interpelación, y no tanto a la situación gubernamental misma. Una reflexión limitadora de este tipo puede modularse en su caso con una eventual revalidación de la mayoría por parte del partido gubernamental; esa diferencia entre las prorrogatios formales o materiales que apuntó Revenga Sánchez ( Gobierno en funciones», Gobierno y Administración en la Constitución, 1988). Elvira Perales tras destacar la posibilidad de control realiza una interesante reflexión sobre el autocontrol de los parlamentarios en esos períodos, apostando por practicar «el menos es más, es decir que la labor de control se mida por la calidad y no por la cantidad», para lograr con ello «un control más efectivo y una mayor repercusión en la opinión pública».

La limitación previa a la que el propio instituto del Gobierno en funciones nos aboca, órgano destinado a solventar situaciones de necesidad, hace compleja una reflexión en abstracto (desvinculada de los concretos acontecimientos que se produzcan - especialmente su duración temporal-), acerca del control parlamentario. Ahora bien, lo que sí resulta claro es que nos encontramos ante la 
instancia más adecuada para la resolución de una acción de control (ahora genéricamente entendida) respecto de un Gobierno en funciones, aunque dicho dato haya de coordinarse con la situación de las Cámaras en los supuestos de celebración de elecciones y con esa necesaria primacía del procedimiento de investidura. En el umbral de la liquidación del Gobierno debe evitarse como apuntó García Herrera que «el Gobierno saliente se proyecte en el futuro y perturbe la orientación y acción del inminente equipo gubernamental» («La continuidad del Gobierno Vasco», RVAP, 1985).

El control parlamentario no puede verse coartado en ninguna de las fases por las que un Gobierno atraviese; cuestión diversa, insistimos, es la modulación de algunos de los instrumentos mediante los que llevar a cabo esta función. Los parámetros de actuación que pueden utilizar las Cortes se revelan en última instancia como los más adecuados a emplear frente al Gobierno durante estos períodos. Esta idea no se contradice en modo alguno con la investidura del nuevo Presidente, con la que finalizará la situación de precariedad del órgano, y a la que en buena lógica deberá concederse una necesaria primacía. El control de un Gobierno en funciones encuentra su sede natural en el ámbito parlamentario, resultando preferible profundizar en la línea de parlamentarización del Gobierno cesante, sin perjuicio del resto de controles que pudieran arbitrarse (Aguiar de Luque, «La posición del Gobierno cesante o en funciones en el ordenamiento constitucional español», El Parlamento $y$ sus transformaciones actuales, Garrorena -ed.—, 1990); los criterios en ocasiones ambiguos que orientan la actuación del Gobierno en funciones, también su abstención, así como las circunstancias que pueden sucederse, «hacen más interesante el control político que el jurisdiccional» (González Alonso, «Los gobiernos cesante y en funciones en el ordenamiento constitucional español, Asamblea, 12, 2005).

Hecha esta apreciación, resulta cierto que, si volvemos la mirada atrás en el tiempo, el control parlamentario se ha ejercido muy limitadamente sobre un Gobierno en funciones, sobre la base, especialmente, de lo acotado de su período de actuación.

Junto a ello, no ha resultado extraño la admisión de iniciativas y la remisión al Gobierno, pero suspendiéndose a la par el cómputo de los plazos para que fuera el nuevo Gobierno, una vez constituido, el que les diera debida respuesta. Una práctica conectada con la certeza de la próxima investidura pero que, como apuntó De la Peña supone «cercenar la potestad parlamentaria de control del Ejecutivo, siquiera con carácter provisional», teniendo dicha actuación un «dudoso encaje con el espíritu constitucional» ( «El control parlamentario del Gobierno en funciones a la luz de la Constitución», Parlamento y control del Gobierno, 1998). Estas cuestiones fueron abordadas en la primera reunión de la Mesa del Congreso en la efímera XI Legislatura, encomendándose a la Secretaría General un Informe sobre la actividad de la Cámara durante el período en que el Gobierno se encuentra en funciones (Informe de 19 de enero de 2016, al que hemos hecho referencia con anterioridad).

La actitud del Gobierno, con su negativa al control, terminó provocando, como es bien sabido, la presentación de un conflicto de atribuciones, todavía pendiente de 
resolución por el Tribunal Constitucional, en el que se alegó una amplia relación de artículos de la Constitución (arts. 1, 9, 23, 66, 108, 109, 110 y 111).

Tras la presentación del conflicto se siguieron produciendo negativas a someterse al control, como por ejemplo con relación a la solicitud de comparecencia en Pleno en el denominado caso Soria. La comparecencia se ventiló finalmente en Comisión a solicitud del propio Ministro, al entender el Gobierno que la Cámara no podía solicitarlo por estar en funciones y ser su única competencia la investidura del Presidente. El Gobierno en funciones llegó a hablar de «fraude de Constitución» sosteniendo que un intento de control iría en contra de la primera tarea de la Cámara, investir candidato.

Pero primar la investidura en el orden del día es una cosa, y obviar el control otra absolutamente diferente; la cuestión no es si cabe el control, sino el alcance, modulación y ajuste de ese control, circunscrito a las competencias que tiene el Gobierno, como hemos señalado con anterioridad. Como se apuntaba en la argumentación del recurso planteado, «la verdadera anomalía constitucional se produciría si se aceptase en nuestro sistema la existencia de un Gobierno en funciones carente de responsabilidad política», donde el órgano representante de la soberanía popular no pudiera comprobar «tanto el hecho de que no excede sus funciones limitadas por la Ley, como el hecho de que las cumple correctamente y no hace dejación de las mismas. Ello supondría admitir la existencia de espacios vacíos dentro del artículo 66 donde el Gobierno podría actuar libremente sin control parlamentario, lo cual se sitúa en las antípodas de lo que representa y significa la forma democrática de nuestro Estado». Por ello, hubiera sido así conveniente, en palabras de Álvarez Vélez al hilo del último traspaso de poderes y del conflicto suscitado, («El control parlamentario. Las incertidumbres sobre el control de un Gobierno en funciones», Asamblea, 35, 2016), que un Gobierno que permanece en funciones «especialmente con la finalidad de no generar ninguna sospecha en su actividad y en defensa de la transparencia hubiera informado a las Cortes de sus actuaciones, por demás «ordinarias», en tanto se estaba dilatando la investidura y el nombramiento de un Presidente y la formación de Gobierno».

Concluimos, coincidiendo con la reflexión de De la Peña («El control parlamentario del Gobierno en funciones a la luz de la Constitución», 1998) cuando señala que la libertad sin control del poder es una quimera, incluso estando el gobierno en funciones.

\section{JOSEFA RIDAURA MARTÍNEZ}

No se entiende el parlamentarismo sin control político. Al igual que tampoco se entiende el Estado de Derecho sin control jurídico de la actuación gubernamental, ejercido por la Jurisdicción Contencioso-Administrativa, y por el Tribunal Constitucional (art. 29 de la Ley 40/2015, de 1 de octubre). La proclamación del Estado democrático de Derecho en nuestro texto constitucional, y la 
sujeción de los poderes públicos a la Constitución y al resto del ordenamiento jurídico (art.9.1 CE), impide que haya actividad exenta de control; en consecuencia, en todo caso, todos los actos de nuestros órganos constitucionales están sujetos a control, bien judicial, bien constitucional, bien político.

Nos centraremos en la primera modalidad de control, que es la que ha generado mayor polémica durante los 341 días en los que el Gobierno ha estado en funciones, suscitada por su posición de no someterse al control parlamentario. En efecto, el Ejecutivo, a través de la Secretaría de Estado de Relaciones con las Cortes, remitió un escrito al Congreso argumentando que el Gobierno en funciones no se iba a someter al control parlamentario, por entender que «ni puede ni debe». «No podemos someternos a las iniciativas de control por parte de una Cámara que no ha otorgado su confianza al Gobierno en funciones», rezaba el comunicado.

En primer lugar, hemos de subrayar que una de las funciones centrales de nuestro sistema parlamentario es la de control político del Ejecutivo. Un control que tiene como uno de sus exponentes la investidura del Presidente, pero que se proyecta a través de múltiples actuaciones parlamentarias. $\mathrm{Y}$, pese a que el texto constitucional expresamente no establezca ninguna previsión al respecto, no se puede excluir el control de un órgano constitucional que sigue ejerciendo, aunque limitadamente, sus funciones. Esta función es consustancial al régimen parlamentario.

Ciertamente, romper una relación fiduciaria que todavía no se ha otorgado, no es posible; por ello determinados mecanismos de exigencia de responsabilidad que tienen como objetivo derrocar al Gobierno no se podrían, lógicamente, plantear. Pero, es que el control político va mucho más allá, de modo que no puede eludirse la fiscalización de un órgano que sigue actuando y tomando decisiones, limitadas, pero decisiones; y que no son sólo de naturaleza materialmente administrativa, sino también política. Precisamente, porque la fiscalización de la acción de un Gobierno alcanza no sólo al Jefe del Ejecutivo, sino la actuación de todo el Gobierno y la Administración.

En definitiva, en el parlamentarismo, por muy racionalizado que esté, se sujeta la acción gubernamental a una constante fiscalización que trasciende las Cámaras, pues permite, substancialmente, que la opinión pública la visualice. Bagehot, en 1867, ya destacaba la relevancia de la función de información con carácter fiscalizador. Esta función, en nuestro entramado constitucional, es la que confiere legitimidad democrática a toda actuación gubernamental, incluso la que desempeñe un gobierno en funciones.

\section{MARÍA ESTHER SEIJAS VILLADANGOS}

La conversión de un supuesto excepcional, Gobierno en funciones, en un hábito, su «rutinización», demanda reflexionar sobre su régimen jurídico y en el mismo cobra un especial protagonismo la cuestión del control. La función del 
control del Gobierno por parte del poder legislativo se concibe como elemento irrenunciable de nuestra forma de Gobierno parlamentaria, el parlamentarismo «como método de Gobierno y como sistema político» (Schmitt, 1923), y garante de su fundamentación democrática. La totalidad de la actividad parlamentaria está impregnada de la esencia del control, un control imbuido por la crítica, la publicidad y la polivalencia funcional. Esa faceta poliédrica del control lo proyecta como control sanción, control ordinario o control orientador de un Gobierno en funciones. Respecto a la eficacia del control parlamentario de un Gobierno en funciones es difícil su valoración objetiva. Su carácter limitado (Guillén, 2002), paralelo a la presunta fugacidad de su tiempo, no nos puede confundir sin embargo al identificar al verdadero destinatario y, a la vez remitente, del control parlamentario, el electorado (García Morillo, 1990). La esencia del control radica en la significación de quien controla, la oposición, frente al sujeto controlado. En momentos donde los Parlamentos aparecen fragmentados, el control multiplica su virtualidad al presentarse como la forma meridianamente más clara de ordenar unas fuerzas políticas que parecen difuminar sus contornos al obtener un escaño y que deben velar por la idea de representación de todos los ciudadanos.

La conceptuación bilateral del control parlamentario respecto al Gobierno en funciones no ampara su supresión, ni su minoración automática de oficio, por el contrario lo que se asume es una adaptación de dicho control a las peculiaridades funcionales y competenciales del Gobierno en funciones. Hay que controlar lo que hace y que esto no sea más de lo que puede hacer ni menos de lo que debe realizar. Así lo primero, sería articular unos controles objetivos sobre el filtro subjetivo de las actuaciones desarrolladas por el Gobierno en funciones. La imposición de la existencia de un «Gobierno en funciones» (STS 2 de diciembre de 2005, FJ 8. ${ }^{\circ}$ ) tiene su correlato en una acotación de sus atribuciones (Seijas, 2017) materialmente, limitándose al despacho ordinario de los asuntos públicos y a que dichas actuaciones no impliquen nuevas orientaciones, ni valoraciones políticas, ni un ejercicio de la discrecionalidad. Temporalmente, le estaría vedado influir sobre decisiones políticas adoptadas con anterioridad (ex ante) y prospectivamente, ya que ello condicionaría, impediría o comprometería a ulteriores Gobiernos. Razones de urgencia o de interés general pueden amparar actuaciones de un Gobierno en funciones fuera de esas acotaciones, siendo precisamente sobre la subjetiva identificación de estos supuestos donde se ha de agudizar el control, dado que esa etiqueta se aplica autónomamente, mientras que el control es heterónomo. Esos controles han de ser políticos, judiciales y constitucionales (art. 29 LG).

El sujeto pasivo del control del Gobierno en funciones es dicho órgano colegiado, conforme el art. $98 \mathrm{CE}$, pero también «cualesquiera otras autoridades del Estado» (art. 109 CE). La expresa referencia del art. 16. 3 de la Ley del Gobierno a Directores de los Gabinetes del Presidente, a los Vicepresidentes y a los Ministros, que continuarán hasta la formación del nuevo Gobierno, les hace destinatarios expresos de dicho control, al compartir ese mismo estatus en funciones. Los considerados por la Ley 3/2015, reguladora del ejercicio de altos cargo de la 
Administración General del Estado, (art. 1.2 CE), serán igualmente destinatarios expresos en términos subjetivos de dicho control. Sobre si el Congreso puede precisar de modo inamovible y determinista el destinatario de ese control hay que cotejar el carácter colegiado del Gobierno, que deberá responder solidariamente, (108 CE) y el silencio de la Ley del Gobierno sobre la asignación individualizada de funciones — que sí discrimina entre el Presidente del Gobierno en funciones y dicho Gobierno en funciones el no ejercicio de una serie de facultades art. 21. 4 y 5-, por lo cual jurídicamente es endeble tal fijación precisa del destinatario que por, el contrario, se vincularía a la cultura constitucional de respeto entre órganos.

$4^{\mathrm{a}}$. ¿En qué casos o en base a qué circunstancias a su juicio un Gobierno en funciones se puede negar a someterse al control parlamentario? ¿En la Ley del Gobierno vigente o en los Reglamentos del Congreso y del Senado hay apoyatura para que un Gobierno no se someta al control parlamentario de alguna de sus actividades? ¿Qué otra valoración querría realizar sobre el ámbito de actuación de un Gobierno en este estado?

\section{JAVIER GARCIA FERNANDEZ}

Por los motivos expuestos en la respuesta a la pregunta anterior, entiendo que no hay ninguna circunstancia que exima al Gobierno cesante de someterse al control parlamentario.

Empezando por la Constitución, su artículo 66.2 establece que las Cortes Generales controlan la acción del Gobierno. En una lectura rápida de ese precepto podemos concluir que la Constitución no hace distingos entre Gobierno en ejercicio porque ha recibido la confianza del Congreso y Gobierno cesante. Obsérvese que la Constitución habla de la acción del Gobierno, esto es, se trata de lo que Gramática denomina sustanciación del adjetivo (en lugar de «la acción gubernamental») y el dato no es inocuo porque va más allá del concepto acción de gobierno, que se caracteriza por el predicado acción. Por el contrario, estamos ante una frase caracterizada por el sujeto, que es el Gobierno. Luego hay que entender que la Constitución atribuye a las Cortes Generales (y no sólo al Congreso) controlar todas las acciones del Gobierno, sean en ejecución de un programa política aceptado por el Congreso sea en el campo más limitado del Gobierno en funciones.

En cuanto a la legislación infraconstitucional, la Ley 50/1997, de 27 de noviembre, del Gobierno, su artículo 21.3 establece que el Gobierno en funciones facilitará el normal desarrollo del proceso de formación del nuevo Gobierno y «limitará su gestión al despacho ordinario de los asuntos públicos, absteniéndose de adoptar, salvo casos de urgencia debidamente acreditados por razones de interés general, cuya acreditación expresa lo justifique, cualesquiera otras medidas». 
Sin avanzar aún en el comentario de los apartados 4 y 5 del mismo artículo, este apartado 3 nos muestra que la barrera que separa lo que está permitido al Gobierno en funciones de lo que le está vedado es una barrera fundada en conceptos jurídicos indeterminados que el Gobierno puede interpretar de una forma y las Cámaras de otra manera, por lo que no es imposible que se produzca algina discrepancia por parte de alguna de las Cámaras, discrepancia que querrá solventar mediante alguno de los instrumentos de control parlamentario que la Constitución y los Reglamentos parlamentarios prevén. Y si pasamos a las acciones singulares que la Ley del Gobierno prohíbe al Presidente y al Gobierno conforme a los apartados 4 y 5 del mismo artículo 21 nos encontramos con la misma situación pero en un sentido opuesto pues las prohibiciones expresas son tan específicas que es difícil que el Gobierno se las salte pero esas mismas prohibiciones, más los términos indeterminados del apartado 3, nos muestran que un Gobierno tiene un margen de acción relativamente amplio, aunque normalmente de contenido poco político, y más bien de gestión administrativa, lo que nos conduce a la misma conclusión

Y si lo vemos desde la perspectiva de los Reglamentos parlamentarios tenemos que el del Congreso de los Diputados regula los instrumentos de control-información (interpelaciones, preguntas y proposiciones no de ley) sin distinguir si el Gobierno está o no en funciones y no da por decaídos los asuntos por el hecho de que el Gobierno esté en funciones como ocurre, por el contrario, con los asuntos pendientes al disolverse la Cámara. Lo mismo ocurre con el Reglamento del Senado.

Finalmente, la valoración que puedo hacer sobre el ámbito de actuación de un Gobierno en funciones, querría señalar que fue un acierto de la Ley 50/1997, de 27 de noviembre, del Gobierno, disciplinar esta situación que se presta a abusos por parte del propio Gobierno. Lo importante, con todo, es que un Gobierno en funciones sigue siendo un Gobierno y, por ende, ha de someterse al control parlamentario que, como he explicado más arriba, no está condicionado por la existencia previa de una relación de confianza.

En conclusión, entiendo que la situación de Gobierno cesante o en funciones no limita las facultades de control de ambas Cámaras. Desgraciadamente, el Gobierno en funciones de la efímera legislaturas 2015-2016 no lo entendió y actuó como si no estuviera sometido a la Constitución.

\section{ÁNGEL J. GÓMEZ MONTORO}

Como he señalado en la pregunta anterior, entiendo que la acción del Gobierno en funciones está plenamente sometida al control de la Cámara y por tanto, fuera de los casos donde el control presupone una relación de confianza, no creo que existan circunstancias que justifiquen el no sometimiento a los instrumentos ordinarios de control. Debe, además, tenerse en cuenta que, en este 
supuesto, el Gobierno tiene importantes limitaciones derivadas de su interinidad y que ello justifica — junto al control jurisdiccional - una fiscalización aún mayor por parte del Parlamento para asegurar que en su actuación se limita «al despacho ordinario de los asuntos públicos» y asegurar que, si realiza actuaciones de mayor alcance, es por estar ante «casos de urgencia debidamente acreditados o por razones de interés general cuya acreditación expresa así lo justifique», tal y como dispone el art. 21.3 de la Ley del Gobierno. En esta última hipótesis, entiendo que el Parlamento tiene el derecho y la obligación de asegurar que la actuación del Ejecutivo queda dentro de esos márgenes y de examinar, si se diera el caso, la concurrencia de una urgencia especial o de razones de interés general. En esta dirección de un amplio control de los actos del Gobierno en funciones, en los términos señalados en la pregunta anterior, parece apuntar el art. 29.2 LG que dispone sin más matices que «todos los actos y omisiones del Gobierno están sometidos al control político de las Cortes Generales».

Dicho esto, conviene también subrayar que la oposición debe huir de la tentación de utilizar sus facultades de control para una labor de desgaste del Gobierno en funciones orientada única y exclusivamente a debilitar al partido que lo apoya de cara a las siguientes elecciones. Es verdad que los límites de lo que pueden - y debenhacer los partidos de la oposición no van a estar siempre claros, pero no lo es menos que algo de esto hubo durante la pasada legislatura, una muestra más de las carencias en nuestra cultura política a las que me he referido en la primera pregunta. El problema está en que frente a esos posibles abusos en el ejercicio del control, el Gobierno no parece que disponga de instrumentos para su defensa. Pero entiendo que tampoco esto justifica una negativa a someterse a una comparecencia o a una pregunta o interpelación; quien comparece, siempre podrá denunciar y evidenciar lo que considere un uso indebido e incluso torticero de los instrumentos de control.

En cuanto al ámbito de actuación que corresponde al Gobierno en funciones, no creo fácil ni necesario que se pueda detallar más de lo que ha hecho la Ley del Gobierno. Quizás hubiera sido conveniente que la Constitución hubiera dicho algo al respecto, pero creo que no hubiera podido dar sino pautas generales similares a las que, de hecho, se han venido respetando desde la entrada en vigor de la Constitución, también cuando ni siquiera existía la regulación introducida en la Ley del Gobierno. Creo que en situaciones normales, no hace falta más regulación y en crisis como la vivida en la legislatura pasada la solución no pasa por una regulación casuística que nunca podrá prever todas las hipótesis y puede dar lugar a otros problemas, sino por una actuación de Gobierno y Parlamento acorde con las exigencias de la lealtad constitucional.

\section{JOSÉ ANTONIO MONTILLA MARTOS}

Como hemos explicado antes, la situación que hemos vivido durante el largo periodo de gobierno en funciones entre diciembre de 2015 y octubre de 2016 es 
paradójica. El Gobierno en funciones se ha negado a someterse al control de las Cámaras pues no ha obtenido su confianza. Por tanto, adopta las decisiones y ejerce sus competencias sin control político. Pero, a su vez, cuando lo considera conveniente acude a dar cuentas a las Cortes Generales, esto es, el controlado decide libremente en que supuestos va a ser controlado. En este sentido, se ha negado a someterse a preguntas parlamentarias o no ha acudido a comparecencias en Pleno y en Comisión. Por tanto, es pertinente preguntarse en qué casos podría negarse. Procedería reiterar ahora lo expuesto en la respuesta anterior y, en consecuencia, a ella no remitimos.

Finalmente, sobre el ámbito de actuación del Gobierno en funciones sólo dos apuntes. En primer lugar, no es muy realista pensar que un gobierno en cualquier situación puede limitarse al despacho ordinario de los asuntos en una sociedad compleja que requiere respuestas rápidas a problemas múltiples. Es claro que adoptará decisiones de contenido político, aun con las limitaciones que la Ley del Gobierno y la propia jurisprudencia del Tribunal Supremo le ha impuesto. En este sentido, me parece más importante, por un lado, garantizar que sus actuaciones van a estar sometidas a control político, no sólo judicial, específicamente en el Congreso; y, por otro, que se introducen los mecanismos constitucionales para que no pueda alargarse en el tiempo esta situación. En ambos sentidos hemos propuesto modificaciones constitucionales y legales en respuestas anteriores.

\section{MIGUEL REVENGA SANCHEZ}

Creo que la pregunta está contestada con lo que acabo de señalar a propósito de la anterior. Añadiría sólo que, desde el punto de vista jurídico y desde consideraciones de carácter político, la figura de un Gobierno en prórroga de funciones, por muy limitadas que tenga sus atribuciones, siempre habrá de estar habilitado para la defensa del interés general frente a situaciones imprevistas. Esta habilitación tiene que ser necesariamente genérica, como lo es en nuestra Ley de Gobierno, si bien las referencias que aparecen en la misma con respecto a la necesidad de acreditar los casos de urgencia o las razones de interés general, son un argumento más que puede esgrimirse - como ocurre con el presupuesto de hecho habilitante en la figura del Decreto Ley — para defender la pertinencia de un control político parlamentario compatible con el control de naturaleza jurisdiccional.

\section{FERNANDO REVIRIEGO PICÓN}

Las cuestiones relativas al control parlamentario del Gobierno que permanece en funciones han sido respondidas en la pregunta anterior a la que nos remitimos. 
Por lo que hace referencia al último de los puntos, el ámbito de actuación de un Gobierno durante esta situación de interinidad, conviene comenzar apuntando que en el ámbito comparado son muy escasas las previsiones normativas sobre estos períodos. Podemos encontrar apenas genéricas referencias a la continuidad del Gobierno, sin mayores precisiones, siendo mucho menos frecuente establecer de manera expresa que el órgano debe reconducirse, cualquiera que fuera la terminología utilizada, a la ordinaria administración en su actividad. Restringir competencias concretas es todavía mucho más extraño, aunque, cuando se produce, tiende a vincularse alrededor de aquellas potestades incardinadas en el vínculo fiduciario, no en vano éste se encuentra quebrado. Resulta reseñable que es mucho más común establecer limitaciones a nivel constitucional con relación a otro tipo de institutos como la suplencia o la interinidad, quizá por la diferente conformación legitimadora de sus titulares, que en este caso resulta derivada y no primaria. Parece significativo destacar que los primeros preceptos de este tipo (acotación genérica del ámbito de acción del órgano gubernamental durante períodos de interinidad) se plasmaron normativamente en coincidencia temporal con lo que se vino en denominar, en el primer tercio del siglo Xx, parlamentarismo racionalizado (vid. Huber, «Die Stellung der Geschäftsregierung in den deutschen Ländern», Deutsche Juristen-Zeitung, 1932). Con carácter coetáneo a nuestro texto constitucional conviene resaltar las previsiones de la Constitución portuguesa de 1976 que establecía que, antes del examen del programa de Gobierno por la Asamblea o después de su dimisión, el Gobierno debería limitarse a la práctica de los actos «estrictamente necessários para assegurar a gestâo dos negócios públicos».

Tras este pequeño apunte, debemos recordar que la Ley del Gobierno estableció un catálogo de limitaciones en el ámbito de actuación del Gobierno en estos períodos, tanto genéricas como específicas, distinguiendo, dentro de estas últimas, entre facultades del Presidente y del Gobierno, así como diferenciando la celebración de elecciones del resto de supuestos con relación a una concreta limitación.

El problema principal reside lógicamente en la interpretación de los conceptos jurídicos indeterminados que acotan el ámbito normal de actuación y, esencialmente, el del despacho ordinario de los asuntos públicos.

Este concepto, a juicio de la jurisprudencia del Tribunal Supremo, engloba todos aquellos asuntos cuya resolución no implique nuevas orientaciones política ni suponga un condicionamiento, compromiso o impedimento para el Gobierno que se ha de formar (STS de 2 de diciembre de 2005). Medidas que superen este marco sólo podrán adoptarse en casos de urgencia o cuando se aprecien razones de interés general (Parejo Alfonso considera que este último concepto diluye la frontera entre un Gobierno en funciones y un Gobierno ordinario - «La regulación del Gobierno y la Administracion; continuidad y discontinuidad en la política de desarrollo constitucional en la materia», Documentación Administrativa, 246/247, 1997-). 
Ahora bien, el marco dibujado por la Ley 50/1997 deja cuestiones irresueltas que sólo podrán recibir respuesta en el caso concreto, atendiendo a su contexto y consecuencias. Una misma decisión puede quedar dentro o fuera de ese paraguas en función de concretas circunstancias, entre las que no es menor la duración temporal de dicho estado. Se puede transformar así la concepción de lo que se habilita a realizar o no a ese Gobierno, pues lo que en un momento puede considerarse que excede de sus competencias cabe valorarlo en otro de forma completamente diferente. Veámoslo con algunos ejemplos. En abstracto la potestad reglamentaria es connatural a la acción del Gobierno y no parece que deba excluirse de la actividad de un Gobierno en funciones, aunque aquí habrá que tener en cuenta la trascendencia y proyección de los Reglamentos, su carácter o no innovador, el hecho de que traigan como causa o no la trasposición de una Directiva comunitaria, el cumplimiento de plazos pre-establecidos, etc. Descendiendo a cuestiones más concretas (por poner tres supuestos sobre los que ha dictado sentencia el Tribunal Supremo - SSTS de 20 de septiembre y 2 de diciembre de 2005 y STS de 28 de mayo de 2013-) ¿Es la denegación de una petición indulto un acto de ordinaria administración? ¿Y la concesión de una extradición? ¿Y la aprobación de un decreto sobre control de dopaje? ¿Cabe en abstracto una respuesta completamente clarificadora que no deje resquicio a la duda para la práctica totalidad de supuestos? ¿Es lo mismo — por citar ejemplos acontecidos durante diferentes permanencias en funciones - un indulto concedido a un delincuente común, solicitado también por la víctima de su delito, que ha rehecho su vida, que el concedido a un banquero cuya entidad bancaria ha condonado deuda al partido en el gobierno? (sobre el uso de esta facultad en estos períodos vid. el detallado estudio de Guillén, El cese del Gobierno y el Gobierno en funciones en el ordenamiento constitucional español, 2002). Esta misma duda la hemos podido ver recientemente en un caso de gran repercusión mediática durante el traspaso de poderes entre Obama y Trump con relación al indulto de la soldado Manning por el caso WikiLeaks, aunque más por el caso que por la persona, todo lo contrario que en el concedido al multimillonario Rich en el traspaso de poderes entre Bush y Obama y que dio lugar al denominado Pardongate (con relación a este último traspaso puede verse Kumar, Before the oath, 2017).

Si bien durante el último período de permanencia en funciones fueron muchas las voces que abogaron por reformar la ley del Gobierno en esta materia (e incluso crear un cuerpo normativo específico en el que se regularan los traspasos de poderes de forma similar a lo previsto en alguna Comunidad Autónoma), no consideramos oportuno incrementar las limitaciones a un Gobierno cesante. Como tampoco creemos que hacer una relación ejemplificativa de lo que en situaciones de normalidad entra en su ámbito de actuación (otra de las propuestas que se barajaron) resuelva todos los problemas que pueden producirse en estos períodos.

Debemos destacar que durante este período se ha presentado, por parte del Grupo Parlamentario Socialista, una Proposición no de ley instando al Gobierno 
a elaborar un proyecto de reforma de la Ley del Gobierno, donde, tras apuntarse que las previsiones de la Ley del Gobierno otorgan un ámbito funcional genérico que tiene «un potencial expansivo inequívoco que, en la práctica se ha evidenciado harto problemática», se plantean los siguientes objetivos: 1 . Delimitar y precisar el alcance de las facultades del Gobierno en funciones referidas al despacho ordinario de asuntos públicos. 2. Desarrollar los supuestos en que puede estimarse urgente o de interés general la intervención del Gobierno en funciones distinta al despacho ordinario de asuntos públicos y determinar el procedimiento de acreditación de la urgencia para tales casos. A juicio de los proponentes, esta previsión permitirá «contribuir a salvaguardar una pacífica y colaborativa convivencia entre los poderes del Estado presidida por el principio de lealtad constitucional».

En el contorno genérico de actuación del Gobierno en funciones dibujado por el art. 21 de la Ley del Gobierno se enmarcan las cuestiones apuntadas en la proposición no de ley: despacho ordinario de los asuntos públicos (en las leyes de Gobierno autonómicas encontramos también otras expresiones de recorrido similar, como funcionamiento normal de los servicios públicos, normal funcionamiento de la Administración o buen funcionamiento de la administración), y, más allá de ello, como ya hemos señalado, la actuación únicamente en casos de urgencia o interés general.

A nuestro juicio, esta iniciativa no parece que lleve a resolver los problemas que un Gobierno en funciones puede suscitar; más aún, ni siquiera lo hace con el problema que es el que ha centrado esta permanencia en funciones, que no ha sido otro que la insumisión del Gobierno al control parlamentario, que es una cuestión completamente diferente. Parece bastante complejo delimitar de forma exhaustiva todas las cuestiones a las que en un momento concreto un Gobierno en funciones puede enfrentarse. Y, de hecho, una actuación que en un momento concreto puede considerarse que excede el ámbito tolerable, puede que en otro, a la vista de las circunstancias (la propia dilación temporal de la permanencia, por ejemplo), resultara oportuna.

Tampoco es cuestión menor señalar que, en ocasiones, la mala praxis de un Gobierno en este estado no deriva tanto de las acciones como de las omisiones (conectadas a medidas impopulares o eventuales cálculos electorales) y que suele darse en el caso de las permanencias en funciones materiales más no en las formales. Es el pretexto o excusa para la inacción de la que nos habla Bouyssou al analizar las constantes crisis gubernamentales de la Cuarta República Francesa y los tránsitos entre Gobiernos ( «L'introuvable notion d'affaires courantes. L'activité des gouvernements demissionaires sous la Quatrième République», RFSP, 4, 1970).

No parece que sea el ámbito competencial al que debamos prestar una mayor atención, pues, en realidad, lo cierto es que en estos años ha existido un comportamiento bastante ordenado de los diferentes Gobiernos (incluso en la última permanencia en funciones, más allá de algunas cuestiones puntuales, como la prórroga concedida a la empresa Ence para un período de sesenta años cuando 
todavía podía permanecer funcionando aquélla hasta 2018; recordemos además que la decisión fue tomada en enero de 2016 cuando el cambio de Gobierno era una opción muy factible-); quizá siguiendo la apelación de Sánchez Agesta (Sistema político de la Constitución española. Ensayo de un sistema, 1980) a esa reconducción al sentido común o a la lealtad institucional.

A nuestro juicio, reviste mayor interés prestar atención a una de las principales funciones del Gobierno durante estos períodos: favorecer un traspaso de poderes lo más ordenado posible. Como bien señala la Ley del Gobierno, «el Gobierno en funciones facilitará el normal desarrollo del proceso de formación del nuevo Gobierno y el traspaso de poderes al mismo». Al hilo de esto cabe recordar que en algunas comunidades autónomas y en concretos traspasos de poderes se han producido conductas un tanto censurables por parte de los gobiernos salientes con destrucción de materiales y documentos.

Más, ¿cómo dar contenido a estas previsiones?, ¿cómo se configura un ordenado traspaso de poderes que permita al Gobierno entrante tomar el poder de la forma más satisfactoria posible?

Leon Blum (Primer Ministro de Francia en dos ocasiones durante la III República y Presidente del último Gobierno provisional antes de la IV), ya planteaba la importancia de esto hace un siglo de una forma ciertamente ilustrativa: «¿No es espantoso pensar que durante días y más días, en tanto no acabe el lento aprendizaje, los más graves asuntos pueden quedar interrumpidos o que las decisiones urgentes, aquéllas que no se deben aplazar, incumbirán a un hombre que ignora todos los elementos de las mismas?» (La Réforme gouvernementale, 1918) versión en castellano, trad. por García Fernández, 1996- Bastante más recientemente y ejemplificándolo con el caso de Mitterrand en 1981 (también, aunque con menor detalle, con el de Roosevelt en 1933) el prof. Tilo Schabert destacaba que una de las paradojas del poder era que a la hora de acceder al cargo se carecía, en realidad, de poder alguno: «1981. Era el nuevo Presidente de la República y había recibido «todo» el poder correspondiente de manos de su predecesor. ¿Pero qué poder? Los muebles del Elíseo estaban vacíos y con su predecesor habían desaparecido también todos sus documentos» («Un príncipe clásico. François Miterrand frente a una lección comparada de Gobierno», REP, 103, 1999).

Quizá en este punto quepa volver la mirada sobre una reciente ley autonómica (Ley 4/2015, de regulación del proceso de transición entre gobiernos en la Comunidad Autónoma de Extremadura) que fue aprobada como consecuencia de un discutido período de permanencia en funciones (recordemos que en las elecciones anteriores a la aprobación de dicho cuerpo normativo se produjo un cambio de orientación política tras casi treinta años de gobierno de un mismo partido) y que fue articulada sobre los principios de mínima intervención, neutralidad política, lealtad y colaboración, información y transparencia. Esta ley sirve de complemento a la Ley de gobierno y recogió un amplio número de limitaciones al Gobierno cesante. Aunque creemos que esas limitaciones son demasiado encorsetadoras, los puntos referentes exclusivamente a la gestión del traspaso de poderes sí que nos 
resultan ciertamente interesantes, y de hecho se activan con relación al propio candidato a la presidencia, razón por las que las traemos a colación.

De esta forma, se prevé allí un acuerdo de traspaso en el que el Gobierno que deja el poder informa al entrante de los asuntos pendientes, estado de tramitación de los mismos, inventario de documentos y la información presupuestaria y contable (estado de ejecución del presupuesto del ejercicio en curso, disponibilidades existentes en Tesorería, importe de las obligaciones pendientes de pago del ejercicio en curso, importe de los compromisos que afecten a los dos ejercicios siguientes, importe de las operaciones de endeudamiento concertadas en la anualidad en curso, así como sus características e información del estado de ejecución del programa operativo vigente).

Este acuerdo de traspaso se debe acordar de forma previa al cese, al menos en el supuesto de cese más habitual: se adoptará en la última reunión del Gobierno antes de las elecciones; para otros supuestos de cese, en el primero que se celebre tras el mismo.

Junto a ello se establecen previsiones concretas con relación al candidato a la presidencia desde el mismo momento de su propuesta como tal candidato hasta el momento de la investidura. Así, por ejemplo, la posibilidad de acceder a información sobre las reuniones del Gobierno, tanto de forma previa como a posteriori. De esta forma, podrá solicitar, como forma de control al Gobierno en funciones, que se remitan a la Asamblea el orden del día de las reuniones que se vayan a celebrar (que deberá ser remitido al menos cuarenta y ocho horas antes de la celebración) y a posteriori la remisión de las actas de las mismas (con ese mismo lapso de tiempo, cuarenta y ocho horas).

También puede solicitar la constitución de comisiones de traspaso en el seno de la Asamblea para cotejar que el Gobierno en funciones se ajusta a sus competencias y límites, a la par que para favorecer el propio traspaso. Estas comisiones estarán integradas a partes iguales por miembros del Gobierno y/o altos cargos del mismo junto con representantes designados por el candidato a Presidente.

La reciente Ley 5/2017, de 1 de junio, de Integridad y Ética Públicas de Aragón que modificó su Ley de Gobierno establece previsiones similares.

Algo parecido, aunque sin comisiones de traspaso en la asamblea lo encontramos en la Ley 1/2016, de 18 de enero, de Transparencia y Buen Gobierno de Galicia.

Quizá podría valorarse establecer estas cuestiones con relación al Gobierno de la Nación mediante la correspondiente reforma de la Ley del Gobierno y los reglamentos parlamentarios.

\section{M. ${ }^{a}$ JOSEFA RIDAURA MARTÍNEZ}

Es la primera ocasión desde que entró en vigor la Constitución de 1978 en la que se dilata la interinidad un Gobierno en funciones durante cerca de un año y, 
al mismo tiempo, las Cámaras están constituidas y en pleno funcionamiento. Esta situación es la que ha generado el conflicto entre un Gobierno en funciones, que alega que el control de sus limitadas funciones corresponde en puridad a la jurisdicción contencioso administrativa y no al nuevo Congreso que no le ha otorgado la confianza, y un Congreso que defiende la vigencia de su función de control político. Esta actitud ha conducido a la interposición de un Conflicto de atribuciones ante el Tribunal Constitucional planteado por diversos grupos parlamentarios del Congreso. La decisión del Constitucional, que deberá pronunciarse sobre el ejercicio de la función de control político en el marco de un Gobierno en funciones, no ha visto la luz cerca de un año después de su planteamiento. No obstante, el Tribunal ha estimado la petición del Abogado del Estado para que se practique una prueba relativa a la solicitud de datos sobre un antecedente de los años noventa; decisión que ha permitido que cesara la interinidad gubernamental sin pronunciamiento del Tribunal sobre el fondo del asunto.

El texto constitucional establece que el gobierno responde de su «gestión política» ante el Congreso (art. 108); y, en sucesivos preceptos contempla una serie de mecanismos a través de los que se articula dicho control: por ejemplo, la facultad de que las Cámaras y sus Comisiones puedan recabar, a través de sus Presidentes, la información y ayuda que precisen del Gobierno y de sus Departamentos y de cualesquiera autoridades del Estado y de las Comunidades Autónomas (art. 109). Así como la posibilidad de reclamar la presencia de los miembros del Gobierno; que tienen, también la facultad de hacerse oír en ellas (art. 110). Y, finalmente, permite que el Gobierno y cada uno de sus miembros se sometan a las interpelaciones y preguntas que se le formulen en las Cámaras.

Por su parte, la Ley de Gobierno (50/1997) en su artículo 29, al ordenar el control de los actos remarca la sujeción a la Constitución y al resto del ordenamiento jurídico en toda su actuación, del que deriva, tanto el control jurisdiccional como el político. Y, en concreto, al regular el control político ejercido por las Cortes Generales, sujeta al mismo todos los actos y omisiones del Gobierno.

El Reglamento del Congreso de los Diputados prevé que los diputados puedan interpelar al Gobierno y a cada uno de sus miembros, que versarán sobre los motivos o propósitos de la conducta del Ejecutivo en cuestiones de política general, bien del Gobierno o de algún departamento ministerial. Y, en relación con las preguntas que los Diputados pueden formular al Gobierno y a cada uno de sus miembros, sólo se excluye expresamente las que sean de exclusivo interés personal de quien la formula o de cualquier otra persona singularizada, así como la que suponga consulta de índole estrictamente jurídico (186.2). Además, se regulan también las comparecencias de los miembros del Gobierno, en Pleno o en Comisiones a petición propia o o de la Cámara (art. 202 y 203) para informar sobre un asunto determinado.

En consecuencia ninguno de los textos referidos descarta expresamente toda función de control político de un Gobierno en funciones.

Frente a este entramado normativo, alega el Gobierno que entre el tiempo que transcurre entre la elección de los miembros de un nuevo Congreso y la investidura 
de un nuevo presidente, el Gobierno cesante continúa asumiendo determinadas funciones, de gestión diaria, de trámite, es decir, muy limitadas. Así pues la función de control a un Gobierno en funciones corresponde en puridad a la jurisdicción contencioso administrativa y no al nuevo Congreso que no le ha otorgado la confianza.

En primer lugar, en relación con su ámbito funcional, es verdad que su actuación no es equiparable a la de un Gobierno en pleno funcionamiento, ya que viene delimitada por la Ley Ley 50/1997, de 27 de noviembre, cuando establece que el Gobierno en funciones limitará su gestión «al despacho ordinario de los asuntos públicos, absteniéndose de adoptar, salvo casos de urgencia debidamente acreditados o por razones de interés general cuya acreditación expresa así lo justifique, cualesquiera otras medidas (art. 21. 3). El precepto excluye que el Presidente del Gobierno la propuesta de disolución la disolución de alguna de las Cámaras, o de las Cortes Generales; la proposición de un referéndum consultivo; aprobar el Proyecto de Ley de Presupuestos Generales del Estado, Presentar proyectos de ley al Congreso de los Diputados o, en su caso, al Senado; quedando suspendidas las delegaciones legislativas otorgadas por las Cortes Generales quedarán en suspenso durante todo el tiempo que el Gobierno esté en funciones como consecuencia de la celebración de elecciones generales.

Es cierto que los términos «despacho ordinario de asuntos públicos, la acreditación de la urgencia y la razones de interés general» son conceptos jurídicos indeterminados, así se ha destacado en diversas Sentencias del Tribunal Supremo. Pero ni la ordenación que lleva a cabo la Ley de Gobierno ni la comprobación efectiva de los actos desempeñados por el Gobierno durante todo este período excluye, por muy ordinaria que sea, toda actividad política. Y, sólo cuando cuando el Gobierno actúe como órgano de la Administración estará sujeto al Derecho Administrativo. Pero, cuando el Gobierno actúa como órgano político no ejerce potestades administrativas ni dicta actos de esta naturaleza y, por tanto, su actuación no puede calificarse como «administrativa». En consecuencia, no se puede sustraer dicha actuación al control político del Congreso.

En segundo lugar, sentado que el Gobierno en funciones tiene actividad política sujeta a control, se trata de determinar la idoneidad de los mecanismos previstos en la Constitución y en el Reglamento. En este sentido, esta claro que no podrán plantearse aquellos que tienen como objeto la remoción del Gobierno, de forma que serían a todas luces inviables la moción de de censura y la cuestión de confianza; esta última vedada por la propia Ley de Gobierno. Pero, puesto que el control político del Gobierno alcanza también la supervisión de la actividad gubernamental, no puede limitarse la actuación de los diputados (bien individualmente bien como perteneciente al grupo parlamentario), en orden a plantear preguntas, interpelaciones, o solicitudes de comparecencia de miembros del Gobierno. En este sentido, llama la atención que se haya limitado a las ccomparecencias (arts.109 y 110) que se han producido a petición de miembros del gobierno; mientras que en otros casos algunos Ministros no hayan atendido la solicitud de comparecer para dar explicaciones sobre sus departamentos. 
Repárese que el artículo 116 CE, en su apartado 6, establece que la declaración de los estados de alarma, de excepción y de sitio no modificará el principio de responsabilidad del Gobierno y de sus agentes reconocidos en la Constitución y en las leyes. De modo que si el Estado de Derecho prevé que, incluso en situaciones jurídicas tan extremas, no quepa excluir su control, no parece plausible sostener que en una situación de normalidad constitucional como lo es la interinidad gubernamental, aunque está se prolongue más allá de lo razonable, su control político pueda soslayarse.

En definitiva, la exclusión de la función de control político de un Gobierno en funciones conduciría a dejar en suspenso temporalmente una función clave del Congreso, cuando las funciones del Gobierno están restringidas, pero no plenamente.

\section{MARÍA ESTHER SEIJAS VILLADANGOS}

Los argumentos del «no control» del Gobierno en funciones, a partir del Oficio remitido por el Gobierno al Presidente del Congreso de los Diputados el 10 de marzo de 2016 y de las diferentes reiteraciones del mismo por distintos miembros del Ejecutivo, se pueden sintetizar en dos pilares, uno formal y otro material. Formalmente, la exigencia de responsabilidad política al Gobierno solo sería aplicable cuando éste goza de la confianza del Congreso, circunstancia que no existiría en el supuesto de un Gobierno en funciones. Es decir se acuñaría un nuevo principio político de relación interorgánica en el parlamentarismo que sería la «desconfianza» (Freixes, 2016) o el «nexo anti fiduciario». Materialmente, las actuaciones de un Gobierno en funciones son «asuntos que no tienen interés alguno para el control político, pues se trata de actos que se realizan sin implicar directriz u orientación política alguna», siendo el propio Gobierno en funciones quien precisa subjetivamente dicha ausencia de interés. Esa misma catalogación subjetiva se aplicaría a los supuestos en que la actuación se enmarcase en razones de urgencia o de interés general. A mayor abundamiento, otros argumentos de la negativa del Gobierno en funciones a ser controlado por el Congreso aludirían a que la fiscalización por un legislativo renovado electoralmente de un Gobierno formado desde la confianza de un Congreso que le precedió equivaldría a un control retroactivo o un control inter legislaturas que devendría en una mutación constitucional, actuación para la que no existirían antecedentes en nuestra historia. La fundamentación de esta negativa se hallaría en el propio artículo 29.2 LG donde se describen las «omisiones» del Gobierno, omisiones que paradójicamente no se eximen de ser controladas políticamente.

Las razones que hacen temblar los fundamentos de lo sustentado se desgranan sobre anclajes positivos, jurisprudenciales (Reviriego, 2017), políticos y doctrinales. En términos de legalidad, dicho control se articula como garantía constitucional de la soberanía consignada en el art. 1.2 CE, implementada orgánicamente a 
través de las Cortes Generales, que conforme al art. $66 \mathrm{CE}$, representan al pueblo español y entre cuyas potestades se identifica el «control de la acción del Gobierno». De modo expreso, el art. 29.2 de la Ley del Gobierno establece que «todos los actos y omisiones del Gobierno están sometidos al control político de las Cortes Generales». Por su parte, el Tribunal Supremo se ha manifestado sobre la no renunciabilidad del control parlamentario a un Gobierno en funciones al sostener que la condición de «en funciones» de un Gobierno «no tiene que ir acompañada, necesariamente, de la inexistencia de control parlamentario» (FJ 7, STS 2602/2013). Políticamente, un Gobierno en funciones, que ha roto el cordón umbilical con quien le sustentó, sobrevive merced a una legitimación renovada que es la de su eficacia, la necesidad de permanencia de un órgano gestor y administrativo que dé continuidad al Estado.

El control es resultado de una relación entre dos sujetos principales, el Congreso y el Gobierno en funciones, no habilitándose la posibilidad material de desvinculación unilateral por una de ellas. No es tampoco un tema de oportunismo político, merced a la conveniencia o desavenencia entre dichos sujetos. Tampoco es un elemento de propaganda electoral, más en un contexto en el que es reciente la consulta electoral o que, como ha acontecido, se vaticina una nueva de modo inminente. El control sobre el Gobierno en funciones tiene naturaleza constitucional (arts. 9.1, 66 y $108 \mathrm{CE}$ ) con lo que cualquier elusión del mismo es una quiebra de la supremacía constitucional y de su carácter fundamentador de nuestro ordenamiento jurídico.

5a. A la vista de la participación de los Gobiernos y de los Estados en el proceso de decisión de la Unión Europea, ¿podría hacernos alguna reflexión sobre cómo debería articularse en este terreno la actuación de un Gobierno en funciones y sobre si habria de estar sometida a control por parte de las Cámaras?

\section{JAVIER GARCIA FERNANDEZ}

A fortiori el Gobierno en funciones ha de estar sometido al control parlamentario en los temas comunitarios. Al igual que ocurre con la política internacional, la política comunitaria responde a impulsos ajenos a la política nacional, de modo que puede surgir una crisis o una situación de urgente resolución que un Gobierno en funciones se puede ver obligado a adoptar importantes decisiones. Y para eso el Gobierno cesante está legitimado salvo los límites del artículo 21.4 y 5 de la Ley 50/1997, de 27 de noviembre. Pero esta libertad de actuación comporta una mayor responsabilidad que ha de dilucidarse mediante el control parlamentario. 


\section{ÁNGEL J. GÓMEZ MONTORO}

Creo que esta es una de las cuestiones más complicadas, tanto en casos en que España deba dar respuesta a un compromiso adquirido con al Unión como en los supuestos en que deba colaborar en la toma de decisiones relevantes que no puedan quedar al vaivén de las circunstancias políticas internas de los Estados miembros. Como en tantos otros aspectos, la pertenencia a la Unión Europea incide de manera importante en una regulación pensada fundamentalmente para el ámbito nacional. Así, es posible que los compromisos adquiridos por España exijan una decisión por parte del Gobierno que puede considerarse excede de los asuntos ordinarios; y entiendo que, en esos casos, estaríamos ante los supuestos de urgencia o interés general a que se refiere el artículo 21.3 LG, antes citado.

Pero, por lo dicho en las preguntas anteriores, esa actividad está sometida al control parlamentario; y entiendo que, de darse esos supuestos, dicho control se hace especialmente necesario para evitar abusos por parte del Ejecutivo. Y, al igual que ocurre cuando el Gobierno no está en funciones sino actuando con plenitud de competencias, lo ideal será acudir a los mecanismos previos para que la postura del Gobierno sea consensuada con la mayoría parlamentaria.

\section{JOSÉ ANTONIO MONTILLA MARTOS}

La Unión Europea es una unión de Estados y cada uno de los todavía 28 Estados están representados en las instituciones en que así procede por sus respectivos gobiernos. Cuando el gobierno representa al Reino de España en la Unión Europa no puede actuar con facultades limitadas, pues no se hallaría en igualdad de condiciones al resto de los miembros de la Unión. Aunque internamente esté en funciones, en el ámbito europeo debe actuar con la plenitud de facultades que derivan del artículo $97 \mathrm{CE}$. Si esto es así, ello tiene consecuencias sobre el control político de esta actuación. Si no hay límites para su actuación, tampoco puede haberlos para su control. Todo lo contrario. Dado que internamente tiene limitadas sus atribuciones pero en la relación con la Unión Europea debe actuar como un gobierno en plenitud de facultades resulta especialmente importante que todas las actuaciones gubernamentales en ese ámbito sean conocidas y debatidas en sede parlamentaria y cuenten con su respaldo. En este caso, el interés general es evidente y también ante quién debe acreditar esa actuación guiada por el interés general.

Es cierto que la mayoría de los supuestos de control parlamentario a los que ha accedido el Gobierno en funciones durante 2016 han sido relacionados con la Unión Europea. Sin embargo, ha sido planteado como facultad de ser oído o comparecer ante las cámaras, esto es, no se acepta el control por las cámaras pero si el derecho a ser oído y comparecer, rompiendo la relación sinalagmática que caracteriza a ambos órganos constitucionales. Ocurre que, en general, ha concurrido la 
petición de comparecencia con la solicitud por parte de los grupos parlamentarios, especialmente para informar sobre los Consejos Europeos o la cumbre con Turquía en un periodo en el que se han producido en Europa hechos tan relevantes como el Brexit o la crisis de los refugiados.

En definitiva, si en general hemos sostenido que el punto de partida es el control parlamentario de la actuación del Gobierno con limitaciones en su alcance vinculadas a las limitaciones que, a su vez, tiene el Gobierno en funciones en su actuación, dado que en el marco de la Unión Europa no puede actuar de forma limitada, tampoco cabe establecer limitaciones al control parlamentario. A mi juicio, también sería conveniente una mención específica en el artículo 21 de la Ley del Gobierno a la actuación del gobierno en funciones en el ámbito europeo y su relación con las Cortes Generales, especialmente a través de la Comisión Mixta para la Unión Europea.

\section{MIGUEL REVENGA SANCHEZ}

La repuesta ha de estar también en consonancia con lo ya apuntado. Nuestra pertenencia a la Unión Europea y el círculo de la gobernanza en ese nivel de decisión empujan en la dirección de ampliar el elenco de funciones que el Gobierno cesante puede verse obligado a adoptar para no dejar de lado las responsabilidades derivadas de esa pertenencia. Lo que cabe esperar del buen sentido político de quienes tengan que participar en los ámbitos de decisión de la Unión estando en prórroga «interna» de funciones, es que lo hagan bajo una reserva expresa que ponga de relieve la fragilidad política de la situación; una fragilidad que lo sería mucho menos si precisamente en razón de ella, el Gobierno cesante no sólo arrostrara su obligación de dar cuenta de lo actuado ante las Cámaras, sino que intentara buscar «ex ante», en las instancias parlamentarias correspondientes, unos mínimos de apoyo que transmutaran al Gobierno cesante, en esta tesitura, en una especie de portavoz de los puntos de vista expresados en sede parlamentaria.

\section{FERNANDO REVIRIEGO PICÓN}

Corresponde ahora abordar las implicaciones que tiene la permanencia en funciones del Gobierno en la fase ascendente (creemos preciso, no obstante, hacer alguna reseña también, aunque mínima, a la fase descendente desde la perspectiva de la «excusa para la inacción» antes señalada) de participación de España en el proceso decisorio europeo. La actuación de la Unión, y de forma particular su cadencia normativa no puede verse alterada, ni siquiera mínimamente, por estos períodos de transición. Los problemas que puede producir la sucesión, más o menos dilatada, entre Gobiernos (de veintiocho o veintisiete países), debe quedar evidentemente ad intra del propio Estado, vertebrándose todo sobre la base del 
principio de cooperación leal recogido en el Tratado de la Unión. Esto no puede verse afectado en modo alguno por cualquier proceso electoral, situación de interinidad.. que afecte a un Estado miembro. En el caso español en esta ocasión han sido más de trescientos días de interinidad; pero, como sabemos bien, en otro país de la Unión, como Bélgica, acostumbrado a provisionalidades de este tipo, una situación similar llegó a durar más de quinientos días (sobre este proceso, Delpérée, «Gouverner sans gouvernement», Bulletin de la Classe des Lettres et des Sciences Morales et Politiques, 33, 2013). Las cuestiones relativas a la interinidad del Gobierno o su legitimidad disminuida quedan por tanto en el ámbito interno y es aquí donde el control parlamentario cobra especial importancia.

Resulta clara la importancia de la actuación del Consejo Europeo y del Consejo de la Unión Europea, y, asimismo, que muchas de las decisiones de estos órganos (en los que se integran el Presidente del Gobierno en plenitud competencial o en funciones —en el primer caso — y los miembros de su Gobierno —en el segundo-) pueden casar con dificultad con un despacho ordinario de los asuntos públicos; ahora bien, pueden enmarcarse con mayor facilitad dentro de ese otro segundo ámbito de actuación habilitado normativamente, como la urgencia o el interés general. Tampoco debemos olvidar en este punto las reuniones informales de Ministros. Será preciso por tanto analizar con detalle cada supuesto, pero siempre teniendo presente que esa representación por el Presidente del Gobierno o los ministros se conecta con la responsabilidad ante las Cortes Generales, sobre la base de que las eventuales decisiones que puedan tomarse condicionan y determinan las políticas nacionales. Parece oportuno abogar por un control de la postura a defender por los miembros del Gobierno en funciones durante este tiempo. Un control que no debe ser solo a posteriori ni meramente informativo; recordemos que conforme a la Ley 8/1994 por la que se regula la Comisión Mixta para la Unión Europea, el Gobierno debe comparecer, con carácter informativo, ante el Pleno del Congreso con posterioridad a cada Consejo Europeo, ordinario o extraordinario y que la Mesa de la Comisión Mixta decidirá los miembros del Gobierno, Ministros o altos cargos, que deban comparecer antes de la celebración de la reunión del Consejo (en sus reuniones semestrales), a efectos de que puedan manifestar la posición del Gobierno en relación a los asuntos incluidos en el orden del día de la reunión del Consejo. Debe haber un planteamiento previo y una posterior rendición de cuentas. En ese sentido, Gómez Corona apuntará que «el Gobierno aun cuando esté teóricamente capacitado, no debería participar en ningún debate europeo sin escuchar lo que la nueva Cámara tiene qué decirle» pues la «única manera de paliar la falta de legitimidad de un Gobierno en funciones para adoptar decisiones que, aunque inevitables en el tiempo, vincularán al Ejecutivo entrante, es que sea la propia Cámara la que fije esa posición» («Las limitaciones del Parlamento recién constituido durante la prorrogatio gubernamental», RDP, 96, 2016). Recordemos que el Consejo de Estado en su detallado Dictamen de febrero de 2008 en el que abordó la inserción del Derecho europeo en el ordenamiento español, reflexionó detalladamente sobre la fase ascendente de 
participación de España en el proceso decisorio europeo en orden a asegurar que el contenido de las normas comunitarias recogiera adecuadamente las necesidades de nuestro país, vinculado ello también a su posterior aplicación normativa y a que ésta no resultara injustificadamente compleja o disfuncional. Y estas necesidades se conectan de manera inmediata con el cambio de posición del Gobierno durante estos períodos en los que no es indiferente si estamos ante una prorogatio formal o material. Parece lo más prudente abogar por una labor estrecha de cooperación e información entre el Gobierno en funciones y el Parlamento durante estos períodos.

Desde otra perspectiva no puede perderse de vista tampoco la fase descendente y de forma particular la aplicación de determinadas decisiones, no en vano en ocasiones las adaptaciones de determinadas directivas se han dejado (en el caso de prorogatios materiales) a los futuros gobiernos por el carácter impopular de la medida (podemos apuntar por ejemplo una directiva de carburantes en uno de los últimos traspasos de poderes), pese a que el plazo de adaptación vencía casi al tiempo de la toma de posesión y por más que los informes jurídicos encargados por Presidencia para la permanencia en funciones apuntaban que podía procederse a la aprobación de estas normas, sin que ello excediera en modo alguno la competencia de un Gobierno durante estos períodos. Los principios de lealtad y colaboración que deben regir la actuación de un Gobierno en funciones deben evitar este tipo de actuaciones, mejor dicho omisiones, que en ocasiones no son sino meras excusas para la inacción como señalábamos supra (Bouyssou, 1970). Junto a lo apuntado, es obligado citar aquí, por último, la reforma de octubre de 2016 de la Ley de Estabilidad Presupuestaria y Sostenibilidad Financiera que estableció que un Gobierno, incluso en funciones, puede adoptar el acuerdo que fije los objetivos de estabilidad presupuestaria (art. 15.1 de dicha Ley) «cuando como consecuencia de una decisión de la Unión Europea» fuera necesario su revisión, aunque en este caso el acuerdo no podría incluir el límite de gasto no financiero del Presupuesto del Estado (art. 30).

\section{JOSEFA RIDAURA MARTÍNEZ}

Ciertamente, no hay una clara previsión normativa sobre la participación de los Gobiernos y de los Estados en el proceso de decisión de la Unión Europea en estas circunstancias. Y, puesto que la Unión Europea no puede acomodar su actuación a las eventualidades de cada Estado, debe preverse la acción estatal, primero para no dejar de participar en la adopción de medidas de gran calado que se han ido adoptando durante el período en que el Gobierno ha estado en funciones, tanto en el marco del Consejo Europeo como en el de los Consejos de Ministros.

$\mathrm{Y}$, en segundo lugar, debería concretarse también el control político de la actuación gubernamental; de hecho, esta necesidad ya fue advertida por la Abogacía del Estado cuando recomendó al Gobierno en funciones que se sometiera al 
control parlamentario cuando su actividad en este ámbito supusiera dirección política y pudiera comprometer la posición de España para el futuro.

La previsión de la Ley 8/1994, de 19 de mayo, por la que se regula la Comisión Mixta para la Unión Europea, que contempla la obligación del Gobierno de comparecer ante el Pleno del Congreso de los Diputados, con posterioridad a cada Consejo Europeo, ordinario o extraordinario, para informar sobre lo allí decidido manteniendo un debate con los Grupos Parlamentarios, ha de entenderse, sin ninguna duda, aplicable al Gobierno en funciones.

Finalmente, puede destacarse que la previsión normativa en orden a la actuación del Gobierno en funciones ha sido muy puntual, actuándose allí donde la necesidad de adopción de determinadas medidas exigía una ineludible reforma legislativa. Es el caso de la Ley Orgánica 1/2016, de 31 de octubre, con un artículo único mediante el que se incluye una nueva disposición adicional séptima en la Ley Orgánica 2/2012, de 27 de abril, de Estabilidad Presupuestaria y Sostenibilidad Financiera, sobre reglas para el establecimiento de los objetivos de estabilidad presupuestaria y de deuda pública para el conjunto de Administraciones Públicas por un Gobierno en funciones. Regulando la actuación en orden a la revisión de los objetivos ya fijados como consecuencia de una decisión de la Unión Europea. Pero, quedan muchas lagunas por cubrir.

En definitiva, los vacíos normativos en este ámbito deben colmarse, ya que las decisiones adoptadas en el marco de la Unión Europea en períodos de interinidad gubernamental no pueden dejarse al albur de una regulación insuficiente que tenga que suplirse con la cortesía parlamentaria o el sentido común.

\section{MARÍA ESTHER SEIJAS VILLADANGOS}

El funcionamiento de la Unión Europea es el de una organización compleja que se estructura sobre las partes que la integran, lo cual implica la solidaria continuidad en su actuación, incluso cuando una de ellas tiene una situación institucional anómala, en particular un Gobierno en funciones. El ejemplo por excelencia fue el desempeño de la Presidencia de la UE por Bélgica, con un Gobierno en funciones. La alternativa contraria implicaría la paralización de la Unión cuando en alguno de los todavía veintiocho Estados haya elecciones y de ellas derive una dilación para configurar el nuevo Gobierno.

Desde el lado estatal, la problemática se ha de percibir con la misma filosofía, la de minorar la afectación a los asuntos comunitarios y la derivable de estos en el Estado a partir de esa situación coyuntural. El fundamento se complica porque su referente es el de un Gobierno con una naturaleza bifronte y asimétrica que está en funciones en el Estado, pero que a nivel europeo se integra en un Gobierno con plenitud de facultades. La articulación de esos dos roles de un mismo sujeto se complica cuando el Ejecutivo en funciones pretende desvincularse del nuevo Legislativo, rehusando ser controlado. 
Sobre cómo articular este proceso, el bagaje normativo nos lleva al Propio Tratado de la Unión Europea, y en particular a dos de sus Protocolos, el Protocolo 1, sobre el cometido de los Parlamentos Nacionales en la Unión Europea y el Protocolo 2, sobre la aplicación de los principios de subsidiariedad y proporcionalidad. A nivel estatal, la Ley 8/1994, de 19 de mayo, por la que se desarrolla la Comisión Mixta para la Unión Europea (reformada en virtud de la Ley 24/2009, de 22 de diciembre, por la que se buscaba su adaptación al Tratado de la Unión Europea de 13 de diciembre de 2007 y por la Ley 38/2010, de 20 de diciembre, a los efectos de reforzar las funciones asignadas a dicha Comisión) manifestó expresamente cómo canalizar la remisión del Protocolo 1 , en virtud de la cual «el modo en que cada Parlamento nacional realiza el control de la actuación de su Gobierno con respecto a las actividades de la Unión Europea atañe a la organización y práctica constitucionales propias de cada Estado miembro» y la voluntad del respeto a los principios de subsidiariedad y proporcionalidad. En la fase ascendente de formación de la voluntad comunitaria, el papel del control de la participación de los miembros del Gobierno en el Consejo de la Unión Europea requiere una comparecencia previa en la citada Comisión (art. 8). En la fase descendente, aparte de regular la comparecencia en dicha Comisión Mixta para la Unión Europea del Ministro de Asuntos Exteriores o del Secretario de Estado (art. 9), destaca que la Ley preceptúa la comparecencia del «Gobierno» ante el Pleno del Congreso de los Diputados, «con posterioridad a cada Consejo Europeo, ordinario o extraordinario, para informar sobre lo allí decidido y mantener un debate con los Grupos Parlamentarios», por lo tanto es un trámite tasado que no admite subsunción en una genérica negativa al control o a la discrecionalidad del Ejecutivo. La atribución al órgano colegiado Gobierno de tal obligación, se ha precisado convencionalmente por la comparecencia de los Presidentes de Gobierno.

Sentada esta propedéutica normativa, el paso siguiente es vincular esta comparecencia a un Gobierno en funciones. Para ello cabe sostener un postulado general que conectaría la urgencia o el interés general como amparo de dichas actuaciones gubernamentales (ex art. 21.3 LG), para desde ahí vincular los argumentos de control al Gobierno en funciones que hemos analizado. Ese paraguas genérico nos resulta insuficiente, prefiriendo una fundamentación alejada de dichos conceptos jurídicos indeterminados (art. 21.3 LG), y optando por una excepción material en virtud de esa naturaleza singular, bifronte y asimétrica de todo Gobierno en funciones de un Estado miembro de la UE. A ella se vincularía de modo estrecho un determinismo parlamentario de las mismas, en su conformación y en su control. Lo que resulta inviable es que un Gobierno en funciones esté más libre para decidir y negociar en Europa que cuando desempeña su actividad de modo ordinario en el propio Estado. Por esa razón, en ese ámbito material preciso de relaciones con la UE la aquiescencia y el debate debe ser prioritario, actuando el Gobierno en funciones como transmisor a Europa de las decisiones de un Parlamento en plenitud de su legitimidad que representa la soberanía de la 
nación. Cualquier otra alternativa supondría vulnerar el límite a las atribuciones de un Gobierno en funciones ya que su potencial discrecionalidad vincularía y determinaría a futuros Gobiernos. Esta actuación debe prescribirse más allá de la lealtad y colaboración entre órganos.

La interpretación que de esta situación se dio en la XI Legislatura fue vincular tal comparecencia de los miembros del Gobierno en asuntos vinculados a la Unión Europea a la discrecionalidad del Gobierno en funciones, utilizándola como excepción a la pauta general de incomparecencia y fundamento de la praxis del uso selectivo del control parlamentario a determinar subjetivamente por el Ejecutivo. La comparecencia, a petición propia, del Presidente del Gobierno en funciones, ante el Pleno del Congreso de los Diputados, para que, de forma extraordinaria por la «urgencia» de la materia y por encontrarse en funciones, informase sobre el contenido de los asuntos tratados en el Consejo Europeo celebrado en Bruselas, los días 17 y 18 de marzo de 2016 el 6 de abril de 2016. (http://www.congreso.es/public_oficiales/L11/CONG/DS/PL/DSCD-11-PL-7. PDF) no fue nada más que el contrapunto de nuestro parecer a este respecto. No se trata de una concesión que se deba agradecer, más allá del protocolo del discurso parlamentario, sino de un acto debido como consecuencia de esa doble naturaleza del ejecutivo. De poco sirve alegar otras excepciones, como la comparecencia del Ministro de Hacienda ante la correlativa Comisión, el 7 de abril de 2016 para explicar la recomendación recibida por el Gobierno de España de la Comisión Europea acerca de la situación Gobiernos autonómicos respecto a lograr una sostenibilidad económica y limitar el déficit o la del Ministro de Asuntos Exteriores, con fecha de 17 de febrero, para informar con carácter previo sobre el contenido de los asuntos que se trataron en el Consejo Europeo de ese mismo mes, a petición del Grupo Parlamentario Popular o ya en la XII Legislatura, la comparecencia del Secretario de Estado para la Unión Europea con carácter previo al Consejo Europeo de 20 y 21 de octubre de 2016, «de forma extraordinaria y por la urgencia de la materia» (Diario de Sesiones del Congreso de los Diputados, N. 32, 19 de octubre de 2016).

La situación «en funciones» de un Gobierno no debería alterar el funcionamiento de la Unión Europea, minorando el protagonismo y el liderazgo de un Estado. In senso contrario, la situación en funciones de un Gobierno sería una cuestión interna que no afectaría a la plenitud europea de un Estado.

$$
* * *
$$

\section{TiTle: The Acting Government}

ABSTRACT: Following the polemic maintenance of the Acting Government due to the elections on December the 15th (2015) we try to answer some questions dealing with the parliamentary control of the Government after his stoppage. Moreover, it is analyzed the Head of State's action in the ordinary investiture procedure, also some future reforms in the automatic procedure of dissolution of both Cameras, in case of frustrated investitures. 
RESUMEN: Se aborda en esta encuesta, a la vista de la polémica permanencia en funciones del Gobierno que sucedió a las elecciones de diciembre de 2015, las cuestiones relativas al control parlamentario del Gobierno tras su cese. Junto a ello se analiza también la actuación del Jefe del Estado en el procedimiento ordinario de investidura, así como posibles reformas en el procedimiento automático de disolución de las Cámaras para los casos de investiduras frustradas.

Key words: Acting Government, Investiture Procedure, Parliamentary Control, Head of State, European Union.

Palabras Clave: Gobierno en funciones, Procedimiento de investidura, Control parlamentario, Jefe de Estado, Unión Europea. 